UNIVERSIDADE DE SÃO PAULO

INSTITUTO DE GEOCIÊNCIAS

\title{
EVOLUÇÃO SEDIMENTAR DO TABULEIRO DO EMBAUBAL, BAIXO RIO XINGU
}

\author{
Diego Fróes e Souza \\ Orientador: Prof. Dr. André Oliveira Sawakuchi
}

\begin{abstract}
DISSERTAÇÃO DE MESTRADO
Programa de Pós-Graduação em Geoquímica e Geotectônica
\end{abstract}

SÃO PAULO

2015 


\section{Agradecimentos}

À FAPESP pelo financiamento do projeto "Proveniência, transporte e estocagem de sedimentos nos rios amazônicos" (processo 11/06609-1).

A todos os colegas de mestrado que de alguma forma participaram no processo deste trabalho.

Às funcionárias do LeGal Thays e Luciana e do Laboratório de Petrografia Sedimentar, Jordana pela ajuda com os materiais na etapa laboratorial.

Aos biólogos Juarez Pezzuti e Cristiane Carneiro da Universidade Federal do Pará pela atenção com relação ao tema dos Quelônios.

Aos funcionários da base do RAN-IBAMA, e à Secretaria do Meio Ambiente de Senador José Porfírio pela cordialidade e pelo fornecimento hospedagem gratuita em sua base do Tabuleiro do Embaubal durante 0 período de campo, em especial ao diretor da base, Luis Berto Cardoso da Costa, pela visita à praia do Juncal durante a desova das tartarugas, experiência que jamais será esquecida.

Ao professor André Oliveira Sawakuchi, por tudo. 


\section{Índice}

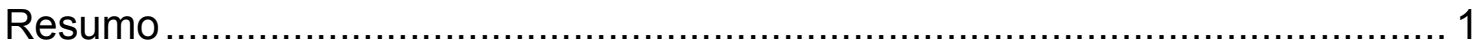

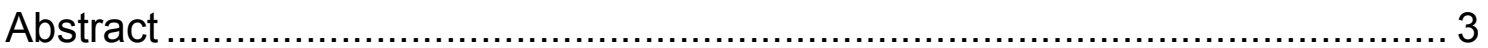

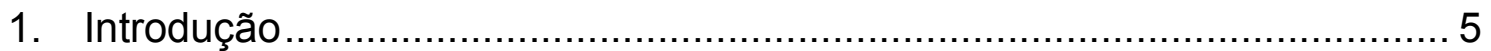

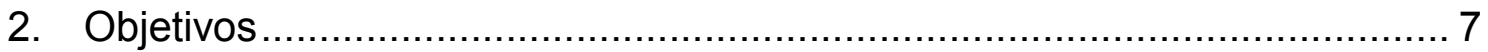

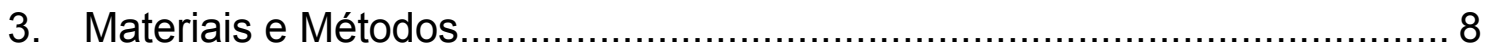

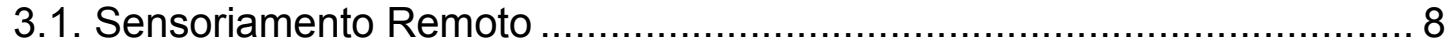

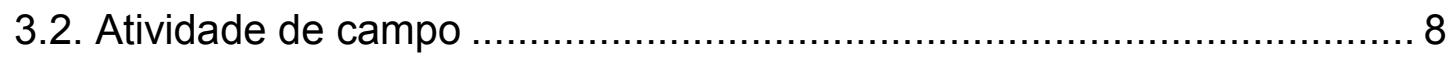

3.2. Análises Granulométricas ........................................................... 9

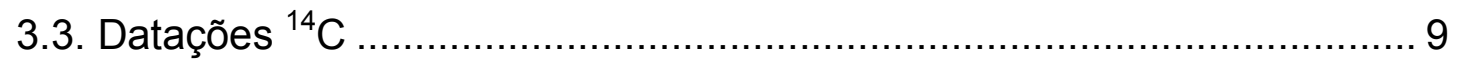

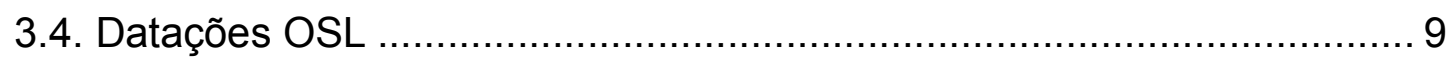

4. Contextos fisiográfico, climático e ecológico....................................... 12

4.1 Localização da área e geologia regional......................................... 12

4.2. Clima e paleoclima da bacia do Xingu ........................................ 16

4.3. Contexto sedimentológico e geomorfológico ................................... 20

4.4. A importância do Tabuleiro do Embaubal para a ecologia dos quelônios amazônicos.......................................................................................... 21

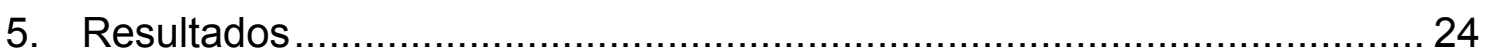

5.1. Análise de fácies sedimentares ............................................... 24

5.2. Geomorfologia das ilhas e interação com a vegetação ripariana .......... 28

5.3. Cronologia de formação e estratigrafia das Ilhas............................... 35

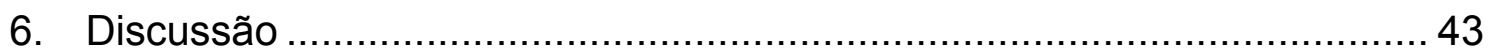

6.1. Modelo deposicional .................................................................... 43

6.2. A formação das ilhas e variações de precipitação durante o Holoceno. 49

6.3. Evolução sedimentar do Tabuleiro do Embaubal ............................. 53

6.4. Possíveis mudanças no Tabuleiro do Embaubal resultantes das barragens do Empreendimento Hidrelétrico de Belo Monte ........................ 54

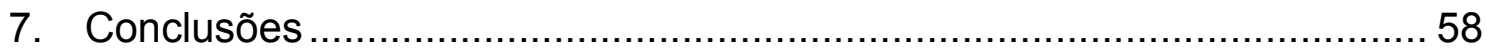

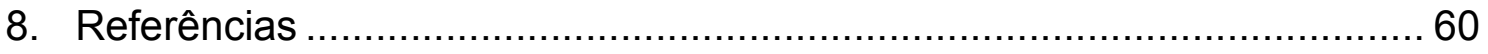


“Pegando carona nas grossas correntes Se vão tartarugas de cascos brilhantes

Que embarcam no rumo de praias distantes

Que servem de berço pra seus descendentes

Que rasgam os ovos e emergem valentes

E correm sozinhas para se salvar

Mas só uma ou outra consegue chegar

Nas águas salgadas que impedem o abraço

Das garras das aves de bico de aço

Que cantam ciranda na beira do mar"

Trecho da música de Siba:

Cantando ciranda na beira do mar 


\section{Resumo}

Este trabalho estabelece a cronologia da evolução do Tabuleiro do Embaubal (TE), situado no baixo rio Xingu (Pará). O TE corresponde ao arquipélago fluvial formado por complexo de barras arenosas estabilizadas por vegetação ripariana. O TE ocorre no trecho em que o rio Xingu adquire morfologia de ria, com ampliação do canal e redução da velocidade do fluxo d'água.

Durante o período de setembro a novembro, ocorre redução do nível do rio e formam-se uma série de praias nas margens das ilhas do TE. Estas praias destacam-se por serem um dos principais locais de nidificação da tartaruga-daamazônia (Podocnemis-expansa) em desova gregária. O TE também destacase pela localização, pois está situado a $32 \mathrm{~km}$ a jusante de onde está localizada a barragem hidrelétrica de Belo Monte, no rio Xingu.

O modelo de evolução sedimentar para a gênese do complexo de barras do TE foi estabelecido utilizando-se as metodologias de datação por OSL (Optically Stimulated Luminescence) e ${ }^{14} \mathrm{C}$.

O substrato sedimentar do TE apresenta uma organização estratigráfica regular: camadas de areia fina a média silto-argilosa (A1) ou areia muito fina siltosa na base (A2), e silte grosso arenoso cinza-claro no topo (S2). De forma que os depósitos $A 1$ e $A 2$, de alta variabilidade granulométrica, estão associados à deposição de barras ativas, enquanto que os depósitos S2 à planície de inundação, fixados pela vegetação. $\mathrm{Na}$ interface entre as fácies A1/A2 e S2 ocasionalmente ocorrem camadas de silte médio argiloso cinzaescuro (S1), sendo este associado aos lagos internos das ilhas.

O modelo proposto demonstra que a evolução das ilhas é resultado da emersão de barras em episódios de baixa vazão, seguidos pela ocupação dessas ilhas pela vegetação. A presença da vegetação adaptada aos episódios de inundação estimula deposição de silte e argila sobre a fácies de areia, prolongando o crescimento das barras para setores de jusante e amalgamando as ilhas.

Segundo os resultados cronológicos, processos de fixação das barras pela vegetação ocorrem em escala secular. A ilhas do TE teriam se formado a 
partir do Holoceno médio, durante os últimos 5000 anos. A deposição de quase a totalidade das barras ocorreu nos últimos 1100 anos, sendo que ainda está ativa, especialmente no norte do TE.

Foi observada forte correlação entre as idades de deposição das barras e variações pluviométricas do Holoceno na região da cabeceira da bacia do Xingu, no centro-oeste do Brasil. Durante a MCA (Medieval Climate Anomaly) e LIA (Little Ice Age) houve intensificação das monções na América do Sul, mesmo período da deposição de grande parte (setor noroeste) das barras do TE.

As alterações da dinâmica sedimentar decorrentes das barragens da hidrelétrica de Belo Monte poderão causar interrupção do ciclo secular a milenar de formação de praias e crescimento de ilhas. Este impacto terá reflexo direto no ambiente de nidificação das tartarugas, pois as areias são provenientes de regiões de montante da barragem principal na calha do rio Xingu. A redução do aporte de areia e da variação sazonal do nível d'água na região do TE poderão gerar cenário onde novas barras serão menos frequentes e menores, com altura de topo inferior e com variabilidade granulométrica inferior a usual e maior proporção de areia fina a muito fina. Isto pode provocar impactos na sexagem das tartarugas (praias de granulação mais fina tendem a estimular nascimento de fêmeas) e no espaço de acomodação das tartarugas. 


\section{Abstract}

This study aims to establish the sedimentary chronology of Tabuleiro do Embaubal (TE), located in the lower Xingu river (eastern Amazônia). The TE is a fluvial archipelago represented by a complex of active or stabilized sand bars covered by riparian vegetation. The TE develops in a sector where the Xingu river acquires a "ria" morphology, with channel widening and water flow velocity reducing.

During the period of low river level from September to November, the emersion of sand bars tops forms a series of beaches. These sandy beaches are among the most important gregarious nesting sites of Tartaruga-daamazônia turtle (Podocnemis expansa). The TE also stands out due to its location at $32 \mathrm{~km}$ downstream from the main dam of the Belo Monte hydropwer plant in the Xingu river channel.

The sedimentary evolution model for the genesis of the complex of bars forming the TE was established using the OSL (Optically Stimulated Luminescence) and ${ }^{14} \mathrm{C}$ dating methods combined with sedimentary facies and geomorphological analysis.

The substrate of TE islands has a regular stratigraphy represented by silty-clay fine to medium sand (A1) or silty very fine sand layers at the base (A2), and light gray sandy coarse silt at the top (S2). The A1 and A2 deposits have high grain size variability and are associated to the deposition of active bars, while the $\mathrm{S} 2$ facies corresponds to floodplain deposits fixed by vegetation. Occasional layers of dark gray clay medium silt (S1) occur between facies $A 1 / A 2$ and $S 2$. Facies $S 1$ is associated with perennial lakes formed within bar or inter-bars depressions.

According to the evolution model proposed for TE development, the islands result from the emergence of bar tops during major episodes of low river level, followed by riparian vegetation occupation. The development of riparian vegetation favors deposition of silt and clay over sand bar tops. Stabilized bars can be elongated through downstream growth and amalgamate to adjacent bars forming wider and longer islands. 
According to the OSL and ${ }^{14} \mathrm{C}$ ages, stabilization processes of sand bars by vegetation growth and muddy sediments deposition occur in secular timescale. The obtained deposition ages indicates that the TE was formed since the Middle Holocene (last 5000 years). Nearly all the bars of the northwest sector of TE formed in the last 1100 years. Deposition of sand bars in the TE is still active, especially in the north sector of the TE.

Strong correlation was observed between the chronology of island development and Holocene rainfall variations in the head region of the Xingu Basin in the central-western Brazil. During the MCA (Medieval Climate Anomaly) and LIA (Little Ice Age) periods, it is registered monsoon intensification in South America, same deposition period of most of the sediments forming the substrate of TE islands.

Changes in sediment transport and deposition due to the dams of the Belo Monte hydropower plant should affect the secular dynamics responsible for the deposition of sand bars and formation of beaches and islands in the TE. It is expected that this impact will directly affect the turtles nesting environment because most of the TE sands are supplied by sector of the Xingu river upstream the dams. In the future, new sand bars are expected to be less frequent, smaller, with lower bar tops and reduced grain size variability (incrase of fine to very fine sand). These changes should cause impacts on turtles sexing (finer sand grain sizes tend to encourage birth of females) and the accommodation space for the turtles. 


\section{Introdução}

Os depósitos sedimentares quaternários associados à feições geomorfológicas dos rios amazônicos possuem cronologia ainda pouco definida. Estudos sobre a sedimentação fluvial na Amazônia têm importância crescente na ciência atual, pois sabe-se que os rios amazônicos desempenham papel fundamental para a biodiversidade (Silva et al. 2005, Ribas et al. 2012) e clima (Cole et al. 2007, Bastviken et al. 2011, Sawakuchi et al., 2014), além de gerarem indicadores paleoclimáticos da maior bacia hidrográfica do mundo (Soares et al. 2010, Bertani et al. 2015). Estabelecer a cronologia de formação de feições geomorfológicas fluviais pode trazer respostas importantes sobre a influência de mudanças climáticas e antrópicas nos ambientes fluviais amazônicos, os quais concentram grande parte da biodiversidade do mundo e têm sido alvo de impactos decorrentes alterações antrópicas, tais como desmatamento e construção de barragens para aproveitamento hidrelétrico (Fearnside 2006).

O rio Xingu é um dos principais tributários da margem direita do rio Amazonas. No seu baixo curso, o rio Xingu adquire morfologia particular caracterizada por corredeiras em canais múltiplos retilíneos que correm sobre sistemas de fraturas e convergem para canal único largo com morfologia de ria fluvial (Archer 2005). O trecho de canais múltiplos retilíneos é conhecido como Volta Grande do rio Xingu. As maiores declividades deste trecho, raras para o baixo curso dos rios Amazônicos, foram cruciais para a localização do Empreendimento Hidrelétrico de Belo Monte, segundo o relatório de impacto ambiental de Belo Monte (Eletrobrás 2009).

Os canais da Volta Grande do Xingu são zonas de transferência de sedimentos arenosos finos a grossos, os quais são depositados no setor de montante da ria (Mineli 2013). Neste setor, situa-se o Tabuleiro do Embaubal (TE), arquipélago fluvial representado por complexo de barras arenosas ativas ou estabilizadas pela vegetação ripariana. O TE se desenvolve no trecho caracterizado pela desaceleração do fluxo do rio, que também sofre influência de ondas geradas por ventos e pela maré. 
A Volta Grande do Xingu e o TE são raridades hidrogeomorfológicas. O estreitamento, divisão e raseamento dos canais do rio Xingu na Volta Grande formam corredeiras e cachoeiras que aumentam a oxigenação da água e propiciam condições particulares para o endemismo de algumas espécies de animais aquáticos (Camargo et al. 2004, Silva et al. 2005). Neste contexto, o TE representa um dos principais locais de nidificação da tartaruga-da-amazônia (Podocnemis-expansa), onde anualmente, nos períodos de setembro a novembro, milhares de fêmeas procuram as praias do arquipélago para depositarem seu ovos (Pearse et al. 2006, Carneiro 2012).

Este trabalho visou estabelecer um modelo de evolução deposicional do TE. Isto envolveu a caracterização faciológica, geomorfológica e geocronológica das ilhas do TE por meio da datação de sedimentos por luminescência opticamente estimulada (Optically Stimulated Luminescence, $O S L)$ e ${ }^{14} \mathrm{C}$. Espera-se que os resultados desta pesquisa irão contribuir para o entendimento da sensibilidade e estabilidade do TE à mudanças no regime hidrosedimentológico do rio Xingu de ordem natural ou antrópica, além de fornecer informações para subsidiar planos de conservação ambiental da região. 


\section{Objetivos}

A meta do trabalho é elaborar um modelo de evolução sedimentar para a gênese do complexo de ilhas do TE, além de propor cenários futuros para o TE, em termos dos possíveis impactos do empreendimento hidrelétrico de Belo Monte. A previsão de cenários futuros para o TE é importante para conservação das populações de quelônios que lá nidificam. O estabelecimento da cronologia de formação do TE permite a comparação entre a evolução do arquipélago e variações de pluviosidade do Sistema de Monção Sul-Americana (SMSA), a qual determina alterações da vazão do rio Xingu. A pequisa envolveu os seguintes objetivos:

1. Elaboração de mapa geomorfológico do arquipélago do Tabuleiro do Embaubal.

2. Descrição das associações de fácies que compõem as ilhas do Tabuleiro do Embaubal.

3. Caracterização granulométrica dos sedimentos que compõem as ilhas.

4. Geocronologia dos sedimentos formadores das ilhas.

5. Elaboração de modelo genético do arquipélago com base nos dados geocronológicos e sedimentológicos obtidos. 


\section{Materiais e Métodos}

\subsection{Sensoriamento Remoto}

As análises geomorfológicas e os perfis de elevação foram realizados a partir de modelos digitais de elevação (DEM) extraídos de imagens SRTM (Shuttle Radar Topogaphic Mission, fonte: www.viewfinderpanoramas.org, baixadas em julho de 2014). Também utilizou-se na interpretação dos dados imagens de radar SAR (Synthetic Aperture Radar) fornecidas gratuitamente pelo SIPAM (Sistema de Proteção da amazônia).

Os perfis topográficos foram elaborados com o software Global Mapper 11. O mapa geomorfológico foi confeccionado com o software QGis.

\subsection{Atividade de campo}

Foi realizada uma atividade de campo para caracterização faciológica das ilhas do TE e coleta de amostras para análises granulométricas e geocronológicas. O trabalho de campo foi realizado entre os dias 21 e 26 de setembro de 2013, período de seca do rio Xingu, durante o qual formam-se praias próximas às margens do canal e afloram escarpas erosivas de barras estabilizadas.

Foram coletadas 49 amostras de sedimentos para granulometria, 23 amostras para datação OSL e 11 amostras para datação ${ }^{14} \mathrm{C}$.

Foram utilizadas embarcações de pequeno porte para o transporte (Voadeiras). Durante o trabalho de campo, foram visitados diversos pontos escolhidos pela análise geomorfológica por sensoriamento remoto. Em cada um dos pontos, amostras foram coletadas para análise granulométrica e foram caracterizadas as fácies observadas em superfície e em profundidade (perfurações a trado manual).

Quando possível, foram descritos perfis e coletadas amostras em afloramentos naturais em margens erosivas do canal. $\mathrm{Na}$ ausência de afloramentos, foram escavadas trincheiras ou realizadas perfurações com trado 
manual. Amostras para datação OSL foram coletadas em afloramentos, trincheiras ou furos a trado por meio de amostrador tipo pistão (piston core) .

\subsection{Análises Granulométricas}

As análises granulométricas foram realizadas em 40 amostras e foram importantes para complementar a análise faciológica realizada em campo.

As análises granulométricas foram realizadas em granulômetro a laser (Malvern Mastersizer 2000) do Laboratório de Sedimentologia do Instituto de Geociências da USP. O método, segundo a teoria de Mie-Fraunhoffer, indica que a variação da difração do feixe no momento que partículas passam aleatoriamente por ele está associada ao tamanho dessas partículas. $\mathrm{O}$ cálculo do tamanho dos grãos foi realizado utilizando o módulo Hydro do equipamento, onde a amostra é agitada e analisada em meio aquoso. Os dados foram representados por curvas granulométricas e estatísticas descritivas.

\subsection{Datações ${ }^{14} \mathrm{C}$}

Fragmentos de folhas e madeira coletados em furos a trado foram separados para datação pelo método ${ }^{14} \mathrm{C}$. As amostras foram coletadas e armazenadas em recipientes plásticos e manipuladas utilizando materiais metálicos para evitar o contato manual. As amostras foram preparadas no Radiocarbon Dating Laboratory do Illinois State Geological Survey, sob os cuidados do Dr. Hong Wang, e encaminhadas para medidas AMS no Lawrence Livermore National Laboratory.

Utilizou-se o software CALIB Rev 7.0.4 (Stuiver \& Reimer 1993) para calibração das idades ${ }^{14} \mathrm{C}$, considerando o intervalo de confiança de $95 \%(2 \sigma)$. Os resultados convencionais apresentados encontram-se em anos antes do presente (AP), sendo presente o ano de 1950. A unidade "cal AP" representa a idade calibrada pelo software CALIBRI.

\subsection{Datações OSL}

As amostras foram coletadas em tubos de alumínio ou PVC para evitar contato com a luz. A datação por luminescência opticamente estimulada (OSL) 
foi realizada no Laboratório de Espectrometria Gama e Luminescência (LEGaL) do Instituto de Geociências da Universidade de São Paulo. A preparação das amostras para medidas OSL em alíquotas de quartzo $(180-250 \mu \mathrm{m})$ foi realizada em ambiente sob iluminação controlada (âmbar/laranja) e envolveu os seguintes procedimentos:

a. Peneiramento a úmido para separação da fração 180-250 $\quad$ mm.

b. Ataque com solução de $\mathrm{H}_{2} \mathrm{O}_{2} 29 \%$ para remoção da matéria orgânica.

c. Ataque com $\mathrm{HCl} 3,75 \%$ para a eliminação de carbonatos.

d. Ataque com HF40\% durante 40 minutos para dissolução dos feldspatos e para eliminação da camada externa dos grãos de quartzo.

e. Separação densimétrica de minerais pesados com solução de metatungstato de lítio (densidade de $2,85 \mathrm{~g} / \mathrm{cm}^{3}$ ).

f. Separação densimétrica de feldspatos remanescentes com solução de metatungstato de lítio (densidade de $2,62 \mathrm{~g} / \mathrm{cm}^{3}$ ).

O cálculo da idade OSL envolve a razão entre a dose equivalente (De, Gy), que corresponde à dose de radiação ionizante acumulada desde o último evento de exposição solar, e a taxa de dose (TD) de radiação (Gy/ka) do ambiente de soterramento (Equação 1).

$$
\text { Idade }=\frac{D e(G y)}{T D(G y / k a)}
$$

Para determinação da dose equivalente, utilizou-se o protocolo SAR (Single-Aliquot Regeneration) proposto por Murray \& Wintle (2003). As medidas OSL foram realizadas em dois leitores Risø OSL/TL reader model DA-20, equipado com LEDs azuis, filtros Hoya U-340 (transmissão na faixa do UV) e fonte de radiação beta $\left({ }^{90} \mathrm{Sr} /{ }^{90} \mathrm{Y}\right)$ com taxas de dose de $0.114 \mathrm{~Gy} / \mathrm{s}$ e 0.084 Gy/s. Curvas de dose-resposta OSL foram obtidas por meio de medidas em alíquotas multigrãos montadas em cups e com o sinal dominado pelo componente rápido $(0,8 s)$ da dose de interesse corrigido pelo sinal de dose teste constante. Utilizou-se os últimos 10 s da curva de decaimento OSL para cálculo do background. Teste de dose (dose recovery test) foi realizado para 
doses administradas de $50 \mathrm{mGy}, 0.42 \mathrm{~Gy}, 35.7$ e $49.98 \mathrm{~Gy}$. As razões entre doses calculadas e administradas foram respectivamente 1,01, 1,00, 0,98 e 0,97 , para temperatura de pré-aquecimento de $200^{\circ} \mathrm{C}$. Deste modo, utilizou-se o protocolo descrito na Tabela 1 para determinação das doses equivalentes.

\begin{tabular}{|c|l|}
\hline Passo & Procedimentos \\
\hline 1. & Dose $\mathrm{D}_{\mathrm{i}}$ \\
\hline 2. & Pré-aquecimento a $200^{\circ} \mathrm{C}$ por $10 \mathrm{~s}$ \\
\hline 3. & Estimulação com LEDs azuis a $125^{\circ} \mathrm{C}$ por $40 \mathrm{~s}\left(\mathrm{~L}_{\mathrm{i}}\right)$ \\
\hline 4. & Dose teste $\mathrm{Dt}$ \\
\hline 5. & Pré-aquecimento até $160^{\circ} \mathrm{C}$ \\
\hline 6. & Estimulação com LEDs azuis a $125^{\circ} \mathrm{C}$ por $40 \mathrm{~s}\left(\mathrm{~T}_{\mathrm{i}}\right)$ \\
\hline 7. & Iluminação com LEDs azuis a $280^{\circ} \mathrm{C}$ por $40 \mathrm{~s}$ \\
\hline 8. & $\begin{array}{c}\text { Repetição dos passos } 1 \text { a } 7 \text { para } \mathrm{D}_{\mathrm{i}}, \mathrm{i}=0-7, \text { sendo } \mathrm{D}_{0} \\
=\text { sinal natural; } \mathrm{D}_{1}<\mathrm{D}_{2}<\mathrm{D}_{3}<\mathrm{D}_{4} ; \mathrm{D}_{5}=0 \text { Gy; } \mathrm{D}_{6}=\mathrm{D}_{7}=\mathrm{D}_{1} .\end{array}$ \\
\hline
\end{tabular}

Tabela 1- Protocolo SAR utilizado para determinação das doses equivalentes das amostras estudadas. A porcentagem do sinal da D5 em relação ao sinal natural foi utilizada como medida de recuperação (recuperation test). A reciclagem (recycling ratio) foi medida pela razão entre os sinais das doses D1 e D6. A medida do sinal de D7 foi realizada após estímulo com infravermelho a $50^{\circ} \mathrm{C}$. A razão entre os sinais das doses D6 e D7 foi utilizada para avaliar a contaminação por feldspatos.

Para cada amostra, foram medidas 24 alíquotas multigrãos de quartzo. Somente alíquotas com razão de reciclagem entre 0,9 e 1,1 , recuperação menor que $5 \%$ e sinal de infravermelho insignificante foram consideradas no cálculo da dose equivalente. As doses equivalentes foram calculadas pelo modelo de idade central (Central Age Model, Galbarith et al. 1999). A amostra EMB13-03 apresentou sinal próximo a zona de saturação (limite do método para o protocolo utilizado). Nesse caso, estimou-se idade mínima a partir da dose de saturação $\left(2 \mathrm{D}_{0}\right)$ do sinal OSL.

A taxa de dose é o resultado da soma da radiação ionizante emitida por radionuclídeos naturais (taxa de dose natural) do ambiente em que o grão ficou soterrado com a radiação cósmica (taxa de dose cósmica).

Os radionuclídeos naturais presentes nos minerais são ${ }^{232} \mathrm{Th},{ }^{235} \mathrm{U},{ }^{238} \mathrm{U}$ e ${ }^{40} \mathrm{~K}$, além dos filhos do Th e U. A concentração dos radionuclídeos foi determinada por espectrometria gama de alta resolução em detector de germânio hiperpuro (HPGe, com eficiência relativa de 55\%) em blindagem ultra-low background. Taxas de dose de radiação foram calculadas a partir das 
concentrações de radionuclídeos por meio de fatores apresentados em Aitken (1998). A absorção da radiação devido à saturação em água (massa de água/massa da amostra seca) no momento de coleta da amostra foi considerada no cálculo da taxa de dose. A taxa de dose cósmica foi calculada utilizando o software Kosmische que utiliza como parâmetros a latitude, longitude, altitude e profundidade de coleta da amostra (Prescott \& Stephan 1982).

\section{Contextos fisiográfico, climático e ecológico}

\subsection{Localização da área e geologia regional}

A bacia hidrográfica do rio Xingu abrange área de $520.000 \mathrm{~km}^{2}$, alongada no sentido sul-norte e limitada pelas bacias hidrográficas dos rios Tapajós à oeste e Tocantins à leste (Figura 1). As nascentes do rio Xingu estão localizadas no centro-leste do Estado do Mato Grosso, próximo ao paralelo $15^{\circ} \mathrm{S}$. O rio Xingu corre predominantemente sentido norte e sua desembocadura no trecho final do rio Amazonas ocorre no nordeste do Estado do Pará, paralelo 1 ${ }^{\circ} 30^{\prime} \mathrm{S}$. A área de estudo, onde o TE está situado, corresponde a um trecho de aproximadamente $133 \mathrm{~km}^{2}$ situado no baixo rio Xingu, a $125 \mathrm{~km}$ da desembocadura no Amazonas, entre os municípios de Vitória do Xingu e Senador José Porfírio, $32 \mathrm{~km}$ a jusante do local de implantação da usina hidrelétrica de Belo Monte. A Figura 1 apresenta a localização do TE.

O TE está situado imediatamente a jusante da zona de transição entre o cráton amazônico, onde o rio Xingu corre principalmente sobre rochas ígneas e metamórficas, e a bacia sedimentar do Amazonas, área dominada por rochas sedimentares fanerozóicas (Figura 2). Segundo Bahia et al. (2004), a área onde situam-se as ilhas do TE está localizada especificamente sobre a Formação Alter do Chão, representada por arenitos grossos e arenitos conglomeráticos. A imagem de satélite da Figura 3 destaca a área do TE, sendo possível observar a grande quantidade de canais que segmentam as ilhas do TE. 


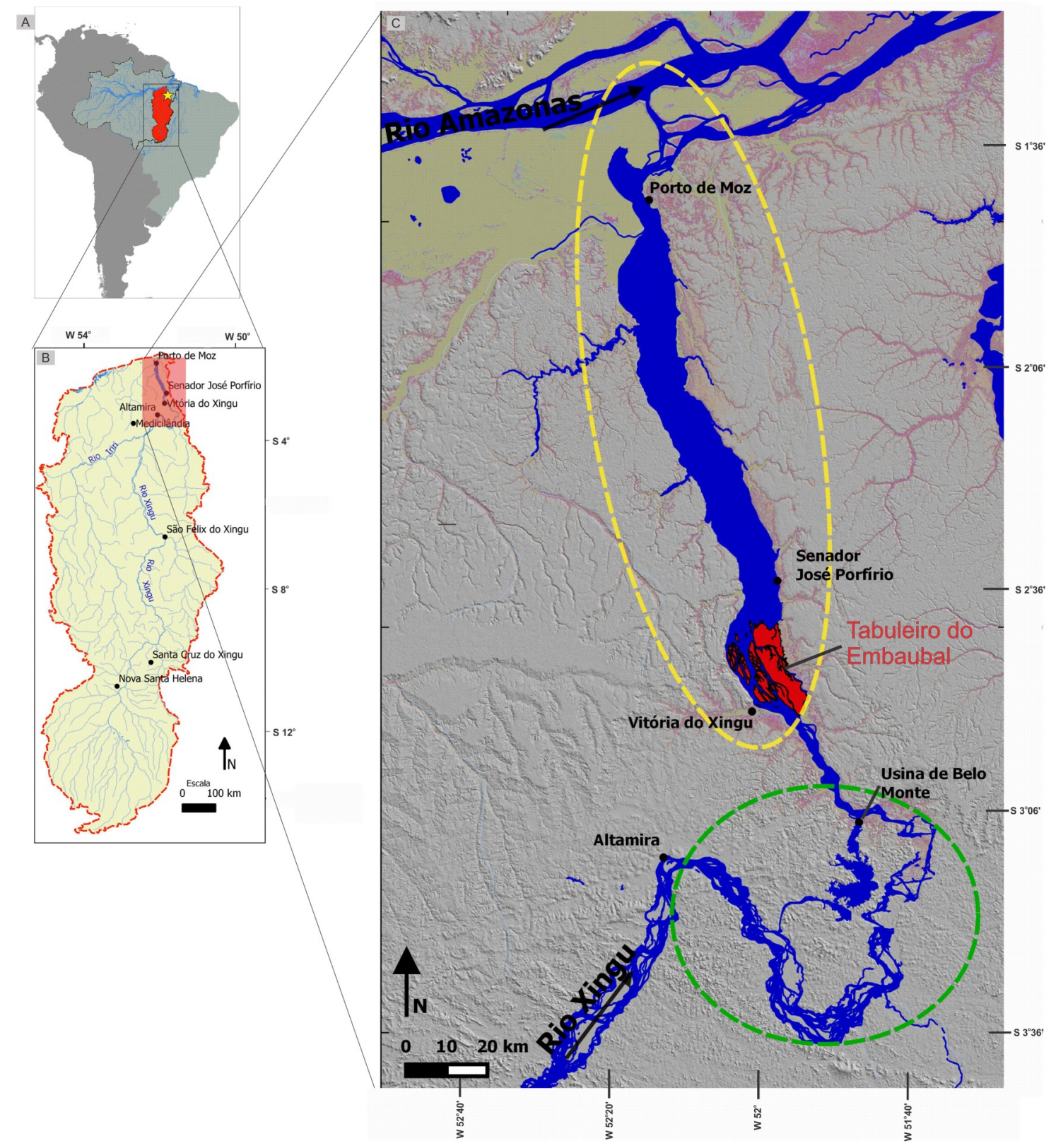

Figura 1 - Localização do Tabuleiro do Embaubal (TE). A: Localização da bacia do rio Xingu. A estrela amarela indica a localização do TE. B: Detalhe da bacia do rio Xingu, com drenagens e principais cidades destacadas. C: Detalhe da região do TE. A região delimitada pela linha tracejada em amarelo corresponde a área onde o rio Xingu adquire morfologia de ria e o círculo verde corresponde a Volta Grande do Xingu. As ilhas do TE estão realçadas em vermelho. À montante da usina de Belo Monte, está o reservatório alimentado por águas desviadas do curso principal do rio Xingu. Fontes: Banco de dados do IBGE, ANA e SRTM. 


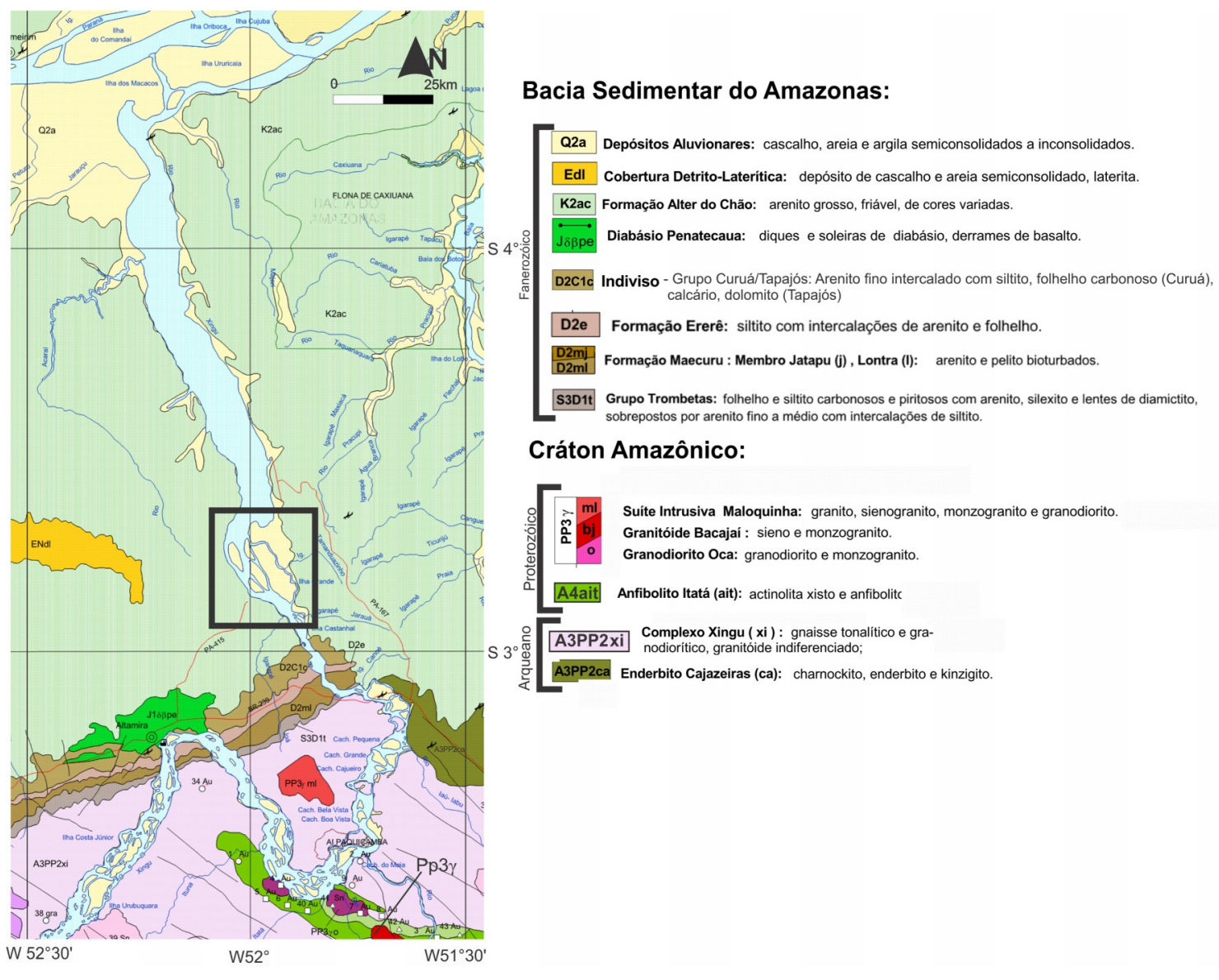

Figura 2 - Contexto geológico da Volta Grande do rio Xingu e Tabuleiro do Embaubal. O complexo de barras do Tabuleiro do Embaubal está destacado pelo retângulo preto. Adaptado de Bahia et al. (2004). 


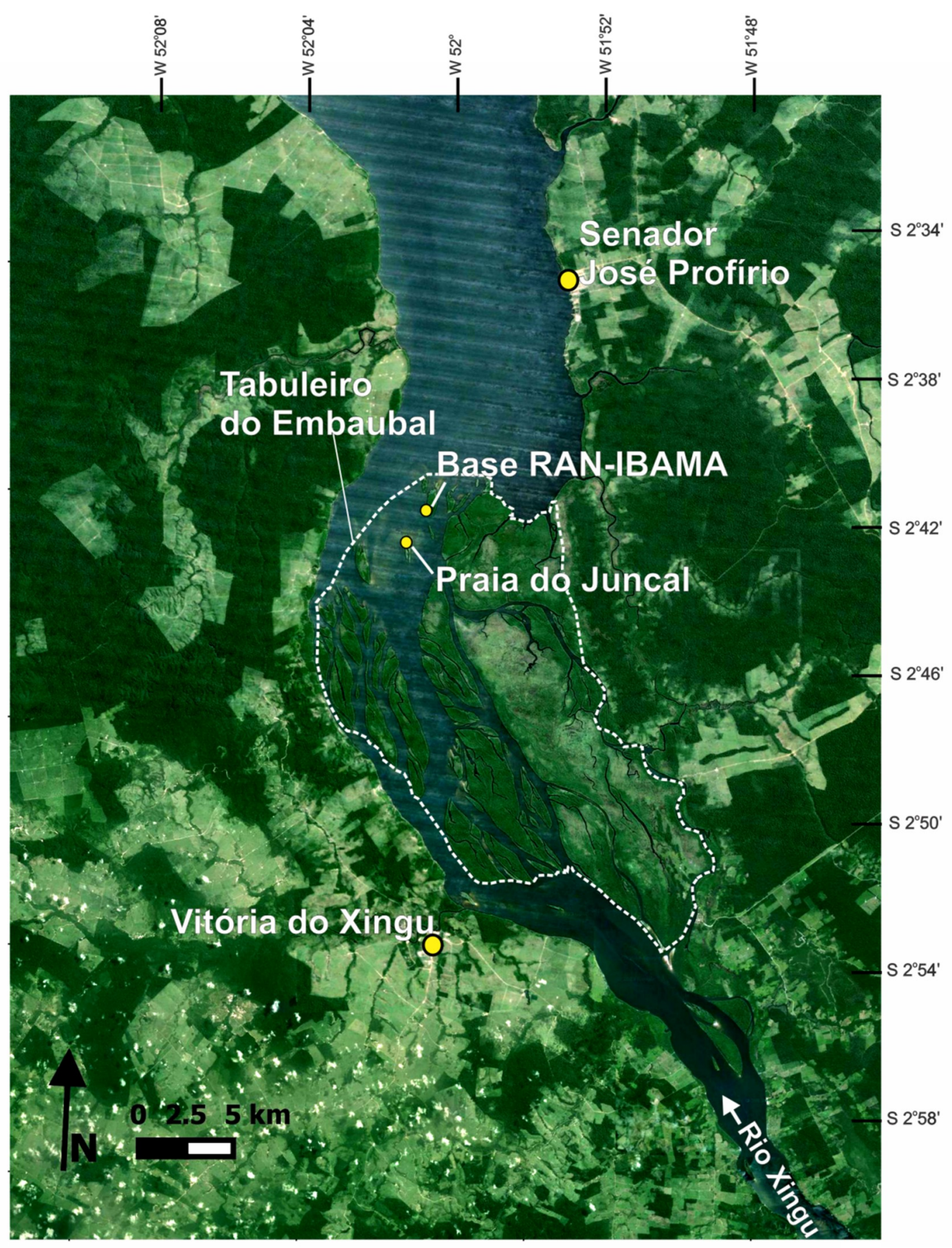

Figura 3 - Imagem de satélite com os limites do TE delimitados pela linha branca tracejada. Fonte: Google Earth (Último acesso: Junho, 2015). 


\subsection{Clima e paleoclima da bacia do Xingu}

A região da bacia de drenagem do rio Xingu apresenta temperatura média de $26^{\circ} \mathrm{C}$ no verão e $28^{\circ} \mathrm{C}$ no inverno e destaca-se pela forte sazonalidade da pluviosidade, com precipitações de $420 \mathrm{~mm}$ mensais no verão e abaixo de 10 mm mensais no inverno (INMET 1992, Figura 4). A grande variação anual do nível do rio e de sua vazão resultam dessa sazonalidade da precipitação. $O$ nível do rio Xingu varia cerca de $6 \mathrm{~m}$ anualmente na região de Altamira, atingindo o nível máximo entre março e abril e o nível mínimo em setembro a outubro (Figura 5).
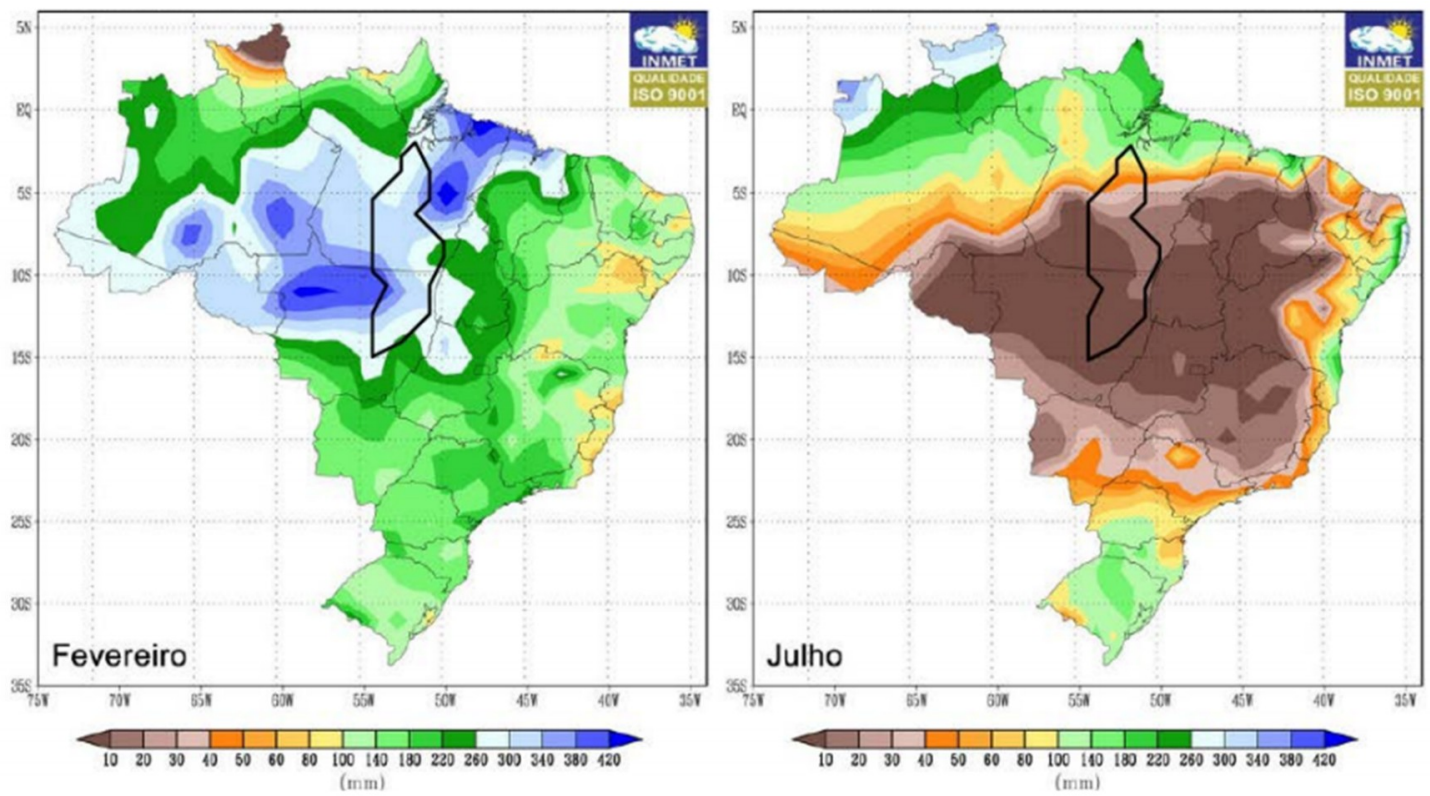

Figura 4 - Normais climatológicas do Brasil no período de 1961 a 1990. Precipitações em milímetros mensais nos meses de fevereiro e julho, correspondentes aos registros médios de precipitação máxima e mínima, respectivamente (INMET 1992). Os polígonos indicam a área da bacia de drenagem do rio Xingu. 

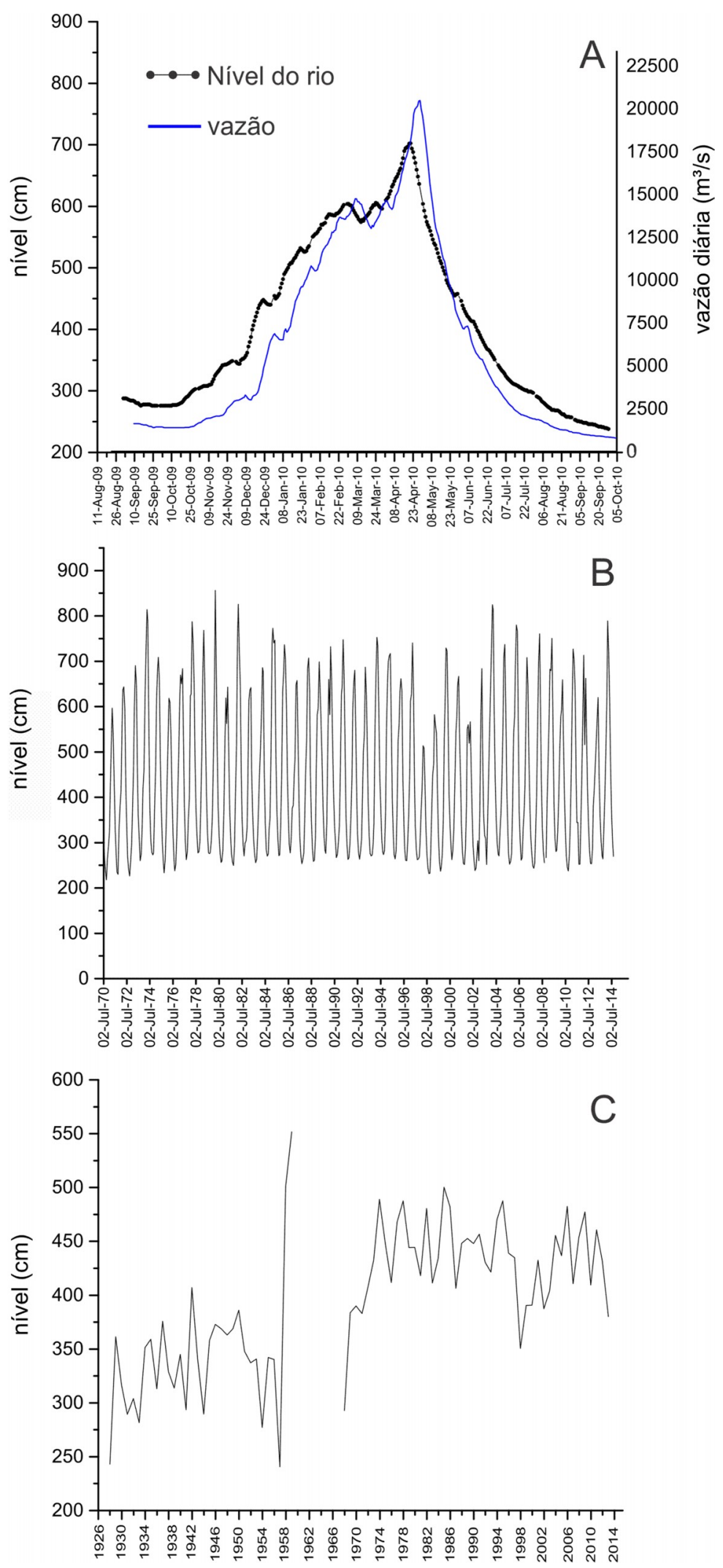

Figura 5 - A: Variação diária do nível e vazão do rio Xingu no período de um ano (2009-2010). B: Série histórica das médias mensais da variação do nível d'água (1970-2004). C: Série histórica com médias anuais do nível do rio Xingu desde 1928. Dados obtidos da Estação Meteorológica de Altamira. (Fonte: ANA - Agência Nacional de Águas 2015) 
Dois regimes de pluviosidade atuam na região da Amazônia. A porção oeste, de floresta tropical, recebe umidade o ano inteiro, sendo maior no verão. A porção leste onde o TE está situado é classificada como tropical de monção (Peel et al. 2007) e recebe umidade durante o verão (Dezembro a Maio).

A série histórica das médias mensais do nível do rio Xingu (1970-2014) reflete o comportamento da sazonalidade do leste amazônico (Figura 4B). A série histórica de médias anuais (Figura $4 \mathrm{C}$ ) realça as variações interanuais da pluviosidade. A série histórica de variação do nível do rio Xingu indica mudança de patamar do nível médio do rio a partir do início da década de 1970, indicando clima persistentemente mais úmido e níveis mais elevados durante as últimas cinco décadas.

Segundo Ferreira et al. (2015), a principal fonte de umidade para a região da bacia do rio Xingu está associada à Zona de Convergência Intertropical (ITCZ, Intertropical Convergence Zone), a qual é caracterizada por faixa de umidade atmosférica que circula no sentido leste-oeste, próxima à linha do equador e que provoca chuva em toda a Zona Intertropical (Syvitski et al. 2014). A forte sazonalidade da região leste amazônica ocorre devido à mudança anual da ITCZ. Durante o verão do hemisfério sul, a ITCZ desloca-se para sul provocando chuva na Amazônia, e durante o inverno, desloca-se para norte, reduzindo a pluviosidade na região e intensificando chuvas na América Central.

A presença da Cordilheira dos Andes também é importante para o controle da pluviosidade na Amazônia. A cordilheira forma uma barreira para a umidade da ITCZ. Isto origina o regime de monções de verão, que provoca precipitação em toda a faixa da SACZ (South atlantic convergence zone), faixa de umidade que percorre desde o oeste da amazônia até o sudeste do Brasil. Dessa forma, mesmo quado a ITCZ se desloca para norte, o oeste da amazônia ainda recebe água de sua porção acima da linha do equador, tornando o clima úmido o ano inteiro (Syvitski et al. 2014).

O papel da vegetação na precipitação da região amazônica também é significativo. Segundo Andreae et al. (2004), aerossóis emitidos para a 
atmosfera por árvores têm papel importante na formação e condensação de nuvens. Assim, alterações na precipitação ocorrem devido ao crescente desmatamento por queimadas durante os períodos de seca.

Trabalhos recentes sobre paleoclima na Amazônia indicam que anomalias negativas de pluviosidade que afetam as porções leste e oeste da amazônia estão associadas ao fenômeno El Niño (Van Breukelen et al. 2008, Cheng et al. 2013, Cruz et al. 2009, Marengo \& Hastenrath 1993). O fenômeno El Niño causa anomalias positivas anuais na temperatura superficial do oceano Pacífico, as quais provocam mudanças de alta magnitude na circulação atmosférica, que enfraquecem as monções tropicais de verão e provocam eventos de seca na Amazônia. Quando essa anomalia é inversa (fria), dá-se o nome de La Niña.

Registros de espeleotemas estudados por Cheng et al. (2013) identificaram comportamentos diferentes da variação da precipitação do leste e do oeste da amazônia em escalas de tempo maiores (ciclos orbitais milenares, $10^{3}$ anos). Os registros indicam que a transição do Holoceno inicial para o médio (early-mid Holocene, entre 8 e $4 \mathrm{ka}$ ) foi um período relativamente mais seco no oeste e úmido no leste. Durante a transição para o Holoceno tardio, a região leste tornou-se relativamente mais seca, e a oeste mais húmida.

A inversão de comportamento climático entre o oeste e leste da Amazônia é denominada por Cheng et al. (2013) como dipolo de precipitação Sulamericano (SAPD, South American Precipitation Dipole), que segundo os autores ocorre porque a concentração de calor e umidade na amazônia, gerada por alta insolação e intenso regime de monção, modifica a circulação em altos níveis troposféricos. Neste processo, feições troposféricas como o Alto da Bolívia (Bolivia High) e o Cavado do Nordeste (Nordeste Low) são intensificadas. Esta última feição é responsável pelo deficit de precipitação na região sob a influência direta da ITCZ durante o verão na região Nordeste do Brasil. Tal mudança climática deve estender também para a área leste da Amazônia, que também é afetada pela ITCZ. 


\subsection{Contexto sedimentológico e geomorfológico}

Segundo Latrubesse et al. (2005), avanços recentes significativos nos estudos de geomorfologia fluvial com enfoque em regiões tropicais têm ocorrido. Ainda assim, se conhece pouco sobre a sedimentação nesses ambientes. Nesse contexto, o rio Xingu é um afluente da margem direita do rio Amazonas, sendo considerado rio de águas claras com baixa carga de sedimentos em suspensão (Sioli 1984). Dessa forma, o rio Xingu representa uma pequena porcentagem da descarga sólida do rio Amazonas quando comparado com demais afluentes de água branca.

O rio Xingu apresenta grande variedade na morfologia de seus canais (Mineli 2013). Na área de estudo, parte mais baixa do curso, o rio Xingu adquire morfologia de ria fluvial, a qual é caracterizada por canal único largo (até $13 \mathrm{~km}$ ) e retilíneo, com as margens em escarpas (falésias fluviais) e com estreitamento do canal na extremidade montante (Figura 6). O complexo de barras fluviais que forma o TE ocorre na zona de montante da ria.

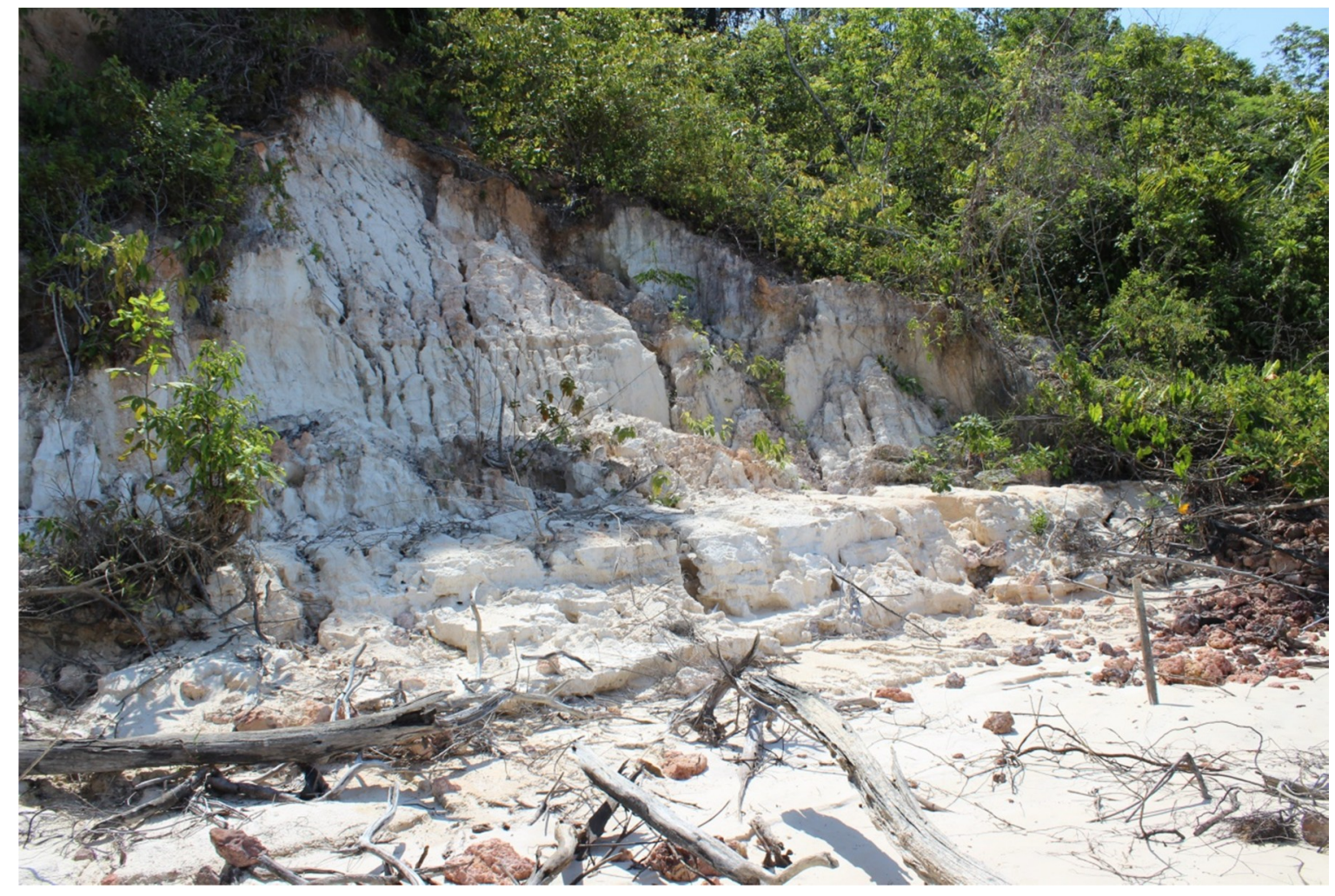

Figura 6 - Margem esquerda da ria do Xingu (ponto EMB 13-24), próximo à cidade de Vitória do Xingu. A escarpa tem cerca de $6 \mathrm{~m}$ de altura. 
Barras e planícies de inundação do rio Xingu na área de estudo são recobertas por vegetação bem adaptada aos episódios de inundação. Esta vegetação tem papel importante na fixação das barras e formação das ilhas. Tratam-se de espécies de vegetação pioneira, que são as primeiras a ocupar o substrato de sedimentos arenosos do topo das barras. Segundo Ferreira et al. (2013), ocorrem na região dois grupos de vegetação, representados por ombrófilas densas aluviais e ripariana aluvial.

Alves (2013) aponta que nas margens das rias ocorrem processos erosivos causados por ondulações que provocam o seu desmoronamento e aumentam a largura do canal. A amplitude da ria permite a formação de corredor de ventos para a formação dessas ondulações. Outros fatores como a influência da maré na variação do nível do rio (Ferreira Júnior et al. 2007) e a circulação de embarcações também intensificam a formação de ondulações e erosão das margens do canal. Segundo Amarante et al. (2001), os ventos predominantes no Estado do Pará têm sentido NE. Assim, os principais agentes responsáveis pela formação dessas ondas são os ventos alísios de direção NE, formados pela circulação da ITCZ. As ondas geradas por estes ventos provocam erosão sobretudo na margem esquerda do canal da ria do Xingu.

\subsection{A importância do Tabuleiro do Embaubal para a ecologia dos quelônios amazônicos.}

O cenário em que vivem os quelônios da amazônia é preocupante pois constituem um grupo de animais que servem tradicionalmente como alimento às populações ribeirinhas e a sua preservação envolve tanto o manejo exploratório como alimento para o homem, quanto a presevação de seus ambientes naturais (Carneiro 2012). Na Amazônia, a construção de barragens representa uma ameaça de destruição sistêmica dos ambientes de reprodução da tartaruga-da-amazônia em escala regional (Alho et al. 2015, Cantarelli \& Verdade 2006, Carneiro 2012, Ferreira Júnior et al. 2007).

Segundo Carneiro (2012), o TE é um ambiente importante de nidificação das tartarugas de água doce, pois concentra uma das maiores populações do 
gênero podocnemis já observadas. As espécies de quelônios que desovam no TE são a podocnemis expansa, conhecida como tartaruga-da-amazônia, a podocnemis unifilis (tracajá) e a podocnemis sextuberculata (pitiú). De acordo com Ferreira Júnior et al. (2007), a tartaruga-da-amazônia representa caso específico de desova gregária porque as fêmeas formam grupos numerosos, com centenas a milhares de indivíduos, para depositarem seus ovos em praias arenosas do TE (Figura 7). Este aspecto é de grande importância para conservação desta espécie de quelônio, o que justifica o monitoramento e manejo da desova pelo Ibama (RAN-IBAMA), com apoio da Secretaria do Meio Ambiente do município de Senador José Porfírio.

Ferreira Júnior et al. (2007) realçam que há grande variação na produção de filhotes. Cerca de 100 mil filhotes foram manejados em 1979 e cerca de 200 mil em 1980. Segundo estes autores, a ação da maré provoca variações (repiquetes) da corrente do rio, as quais elevam o nível d'água e inundam os ninhos mais profundos. Isto explicaria a grande variação no número de filhotes.

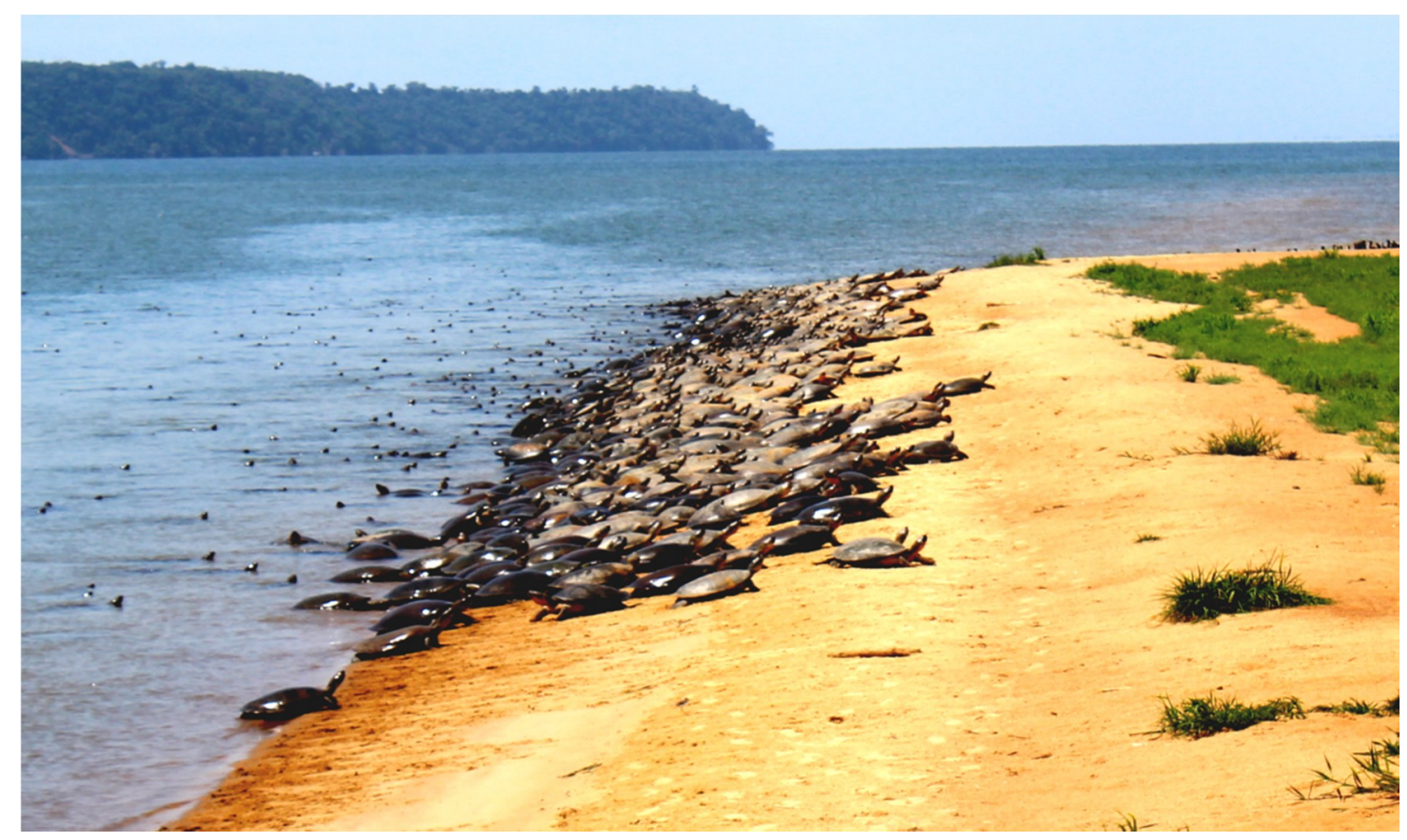

Figura 7- Praia do Juncal, principal local de desova da Podocnemis Expansa (setembro de 2013). A praia foi alteada artificialmente por sedimentos arenosos dragados do canal adjacente. 
Barragens para empreendimentos hidrelétricos em geral provocam isolamento das populações de quelônios, pois impedem movimentos migratórios, transformam ambientes lóticos em lênticos e interferem na dinâmica sedimentar à montante e à jusante da barragem (Carneiro 2012)

Alterações na dinâmica sedimentar também podem causar impacto biológico específico para populações de quelônios. Alterações na temperatura do ambiente de nidificação têm efeito conhecido sobre a sexagem de diversos gêneros de quelônios, incluso o gênero podocnemis (Fadini et al. 2011, Speakman et al. 1998, Matsuzawa et al. 2002, Hays et al. 2003, Ferreira Júnior et al. 2007, Carneiro 2012). A temperatura dos ninhos é determinada tanto pelas características climáticas quanto pelas características físicas do ambiente de nidificação (Carneiro 2012). As características físicas são determinadas pela granulação da areia, onde frações mais finas proporcionariam maior retenção de umidade e conservação de temperaturas mais baixas. A redução da temperatura durante o período de incubação dos ovos induz o desenvolvimento de machos, enquanto que $o$ aumento da temperatura favorece 0 desenvolvimento de fêmeas.

Dessa forma, alterações no regime de sedimentação geradas por fatores naturais ou devido à implantação de barragens podem colocar em risco não somente a manutenção de praias para nidificação, como também podem provocar alterações na sexagem, caso praias de granulação diferentes se formem.

Nesse contexto, os estudos de impacto ambiental realizados para a realização da obra de Belo Monte (Eletrobrás) apontaram diversos riscos do empreendimento hidrelétrico para a população de quelônios do TE, por meio de alterações na sedimentação, e propuseram trabalhos de mitigação para preservação. 


\section{Resultados}

\subsection{Análise de fácies sedimentares}

Os pontos avaliados na etapa de campo, onde foram realizadas as análises faciológicas e coletadas amostras para geocronologia e granulometria estão apresentados na Figura 8. Os pontos de descrição de fácies e coleta de amostras foram selecionados para obtenção de perfis representativos de toda a área do TE.

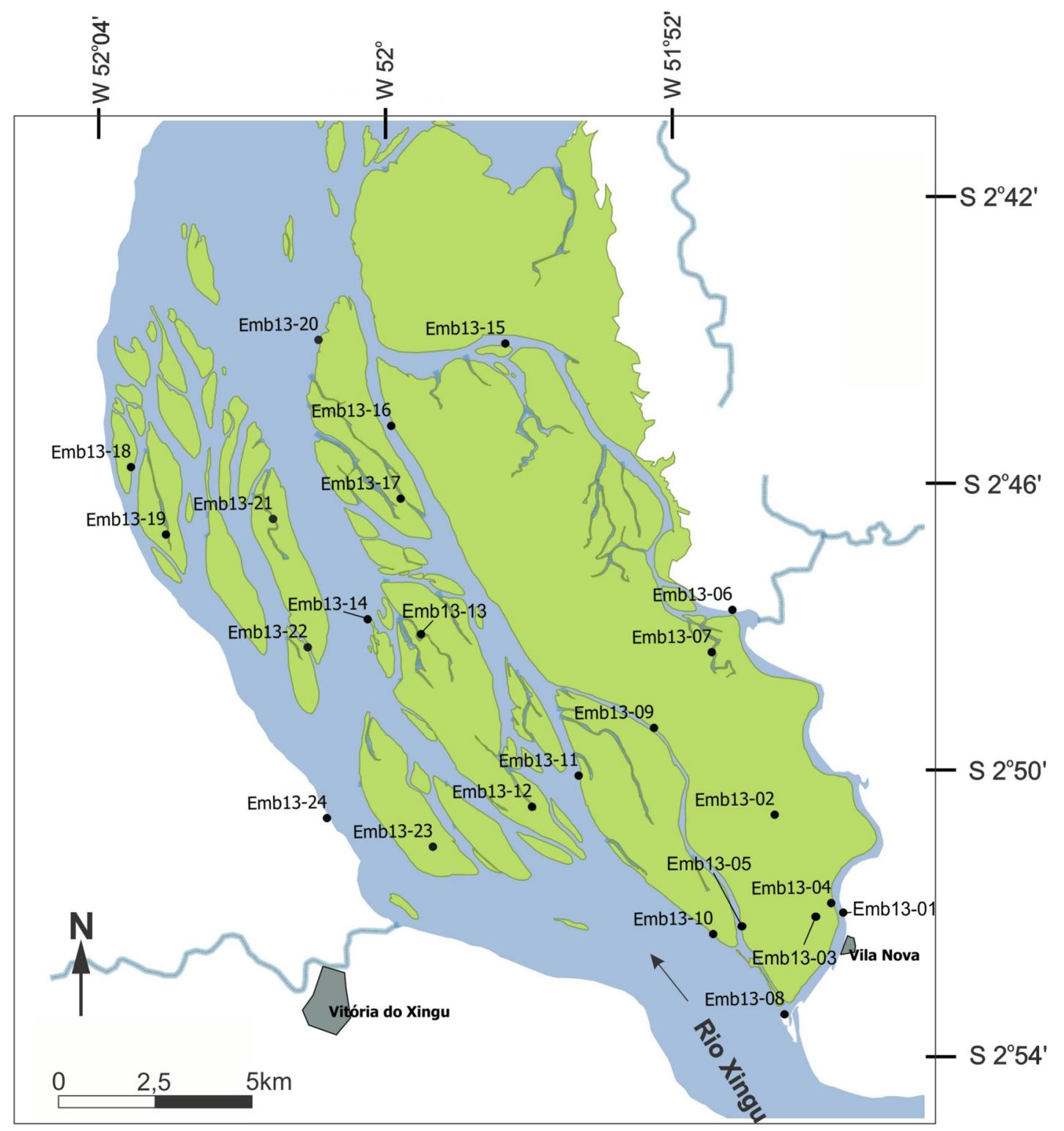

Figura 8 - Localização dos pontos de coleta de amostras para análises granulométricas e geocronológicas (OSL e ${ }^{14} \mathrm{C}$ ) na área do TE. 
Com base na classificação definida em campo e posteriormente complementada pelas análises granulométricas, as ilhas do TE são compostas por quatro fácies sedimentares (Figura 9), as quais são descritas a seguir.

Silte médio argiloso orgânico (S1): caracteriza-se por silte médio argiloso laminado (lâminas argilosas intercaladas com lâminas silto-arenosas), com coloração cinza-escuro e fragmentos de folhas e caules paralelos à laminação.

Silte grosso arenoso (S2): caracteriza-se por silte grosso argiloso maciço, com porções arenosas, manchas alaranjadas de oxidação e coloração cinza claro.

Areia fina a média silto-argilosa (A1): caracteriza-se por areia média a fina maciça ou ocasionalmente estratificada, com porções silto-argilosas, alta variação granulométrica e coloração alaranjada.

Areia muito fina a fina siltosa (A2): areia muito fina a fina siltosa maciça, frequentemente com laminação heterolítica de areia fina intercalada com argila cinza-claro. Pode conter fragmentos vegetais. 


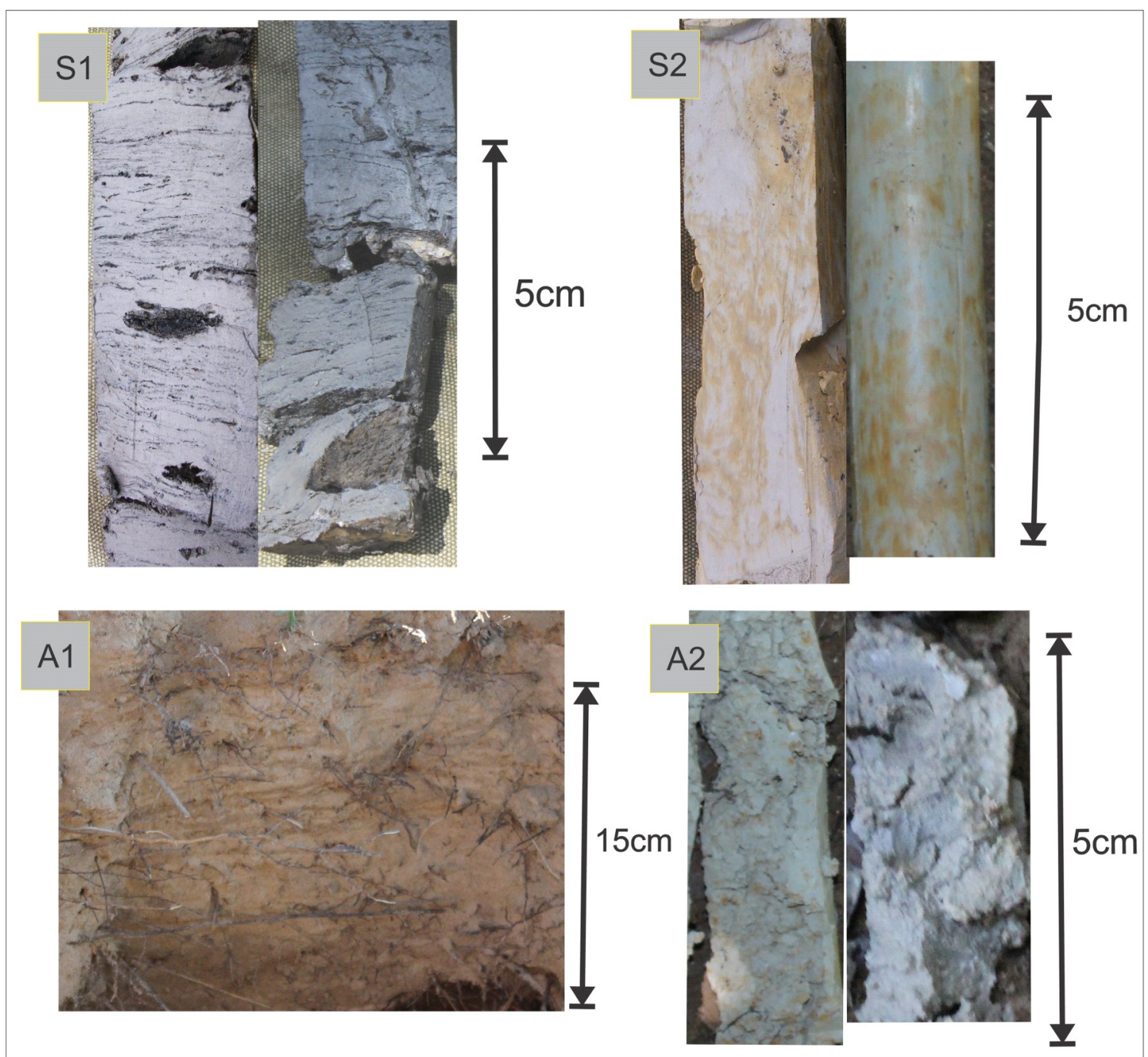

Figura 9 - S1: Fácies silte médio arenoso orgânico com fragmentos de caule e folhas na laminação (ponto EMB-07C). S2: Fácies silte grosso arenoso (ponto EMB-07). A1: Fácies areia fina a média silto-argilosa (ponto EMB13-02). A2: Fácies areia muito fina a fina siltosa (ponto EMB13-21).

A Figura 10 apresenta os dados granulométricos das fácies sedimentares descritas no TE. A Tabela 2 apresenta o resumo estatístico dos dados granulométricos para cada fácies observada. A fácies S1 apresentou moda próxima a média, ambos dentro da faixa de silte fino (phi $=6.15$ ), com baixa assimetria. A fácies S2 apresentou média em silte médio, moda em silte grosso e baixa assimetria. Ambas as fácies siltosas apresentaram baixa assimetria, porém alta curtose indicativa de grande variabilidade granulométrica. A fácies A1 apresentou moda na classe areia fina e média na classe areia muito fina. A fácies A2 apresenta média em silte grosso e moda na classe areia fina. Ambas as fácies arenosas possuem alta assimetria e baixa 
curtose, indicativas de alta concentração de areia significativamente, porém com elevada dispersão nas frações mais finas.

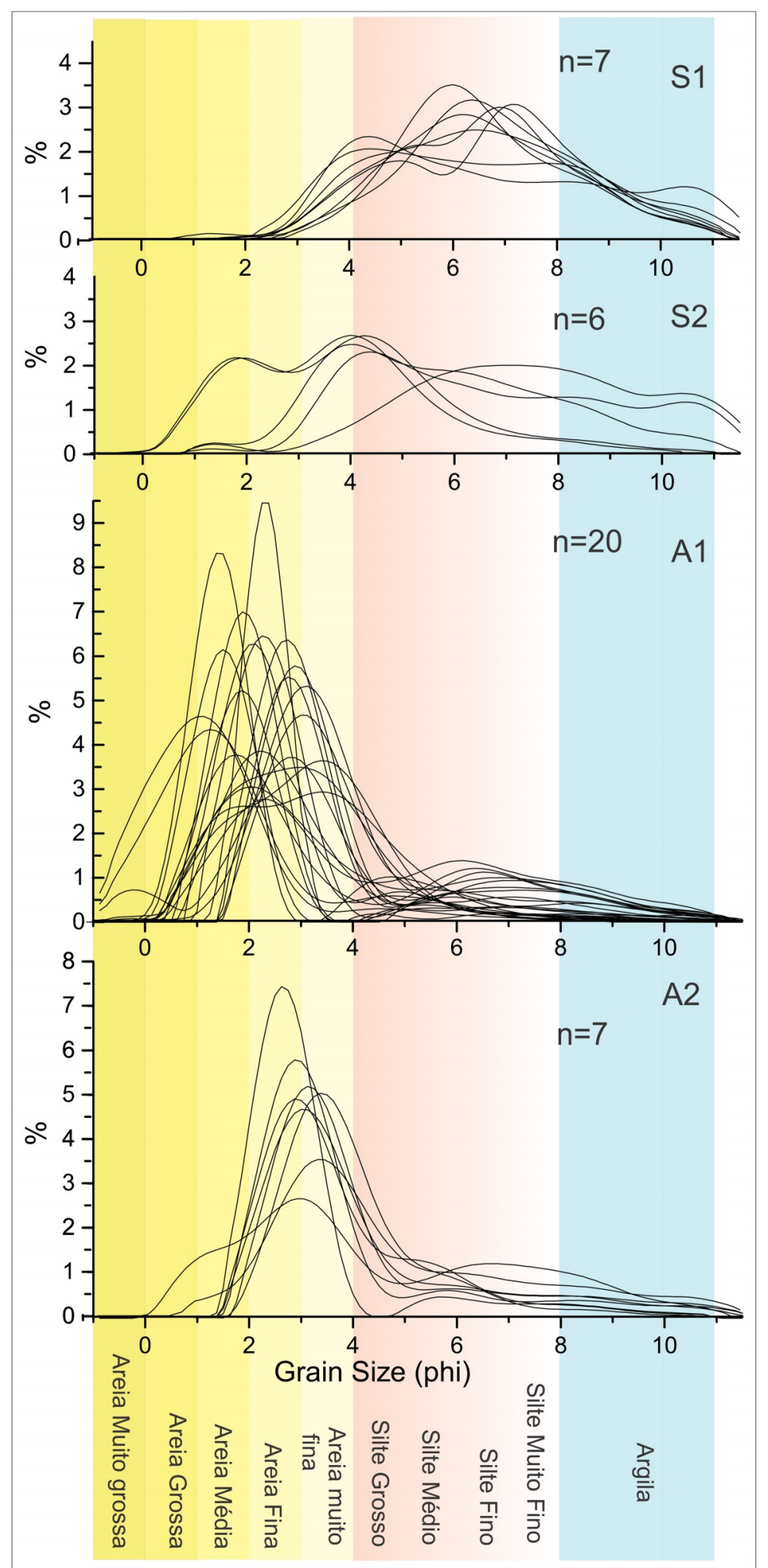

Figura 10 - Curvas granulométricas obtidas para as fácies sedimentares observadas no TE. S1: Fácies silte areno-argiloso orgânico S2: Fácies silte areno-argiloso cinza-claro. A1: Fácies areia silto-argilosa alaranjada A2: Fácies areia siltosa cinza claro. 


\begin{tabular}{|c|c|c|c|c|c|c|}
\hline Fácies & $\begin{array}{c}\text { Diâmetro Médio } \\
\text { (phi) }\end{array}$ & $\begin{array}{c}\text { Desvio } \\
\text { Padrão (phi) }\end{array}$ & $\begin{array}{c}\text { Assimetria } \\
\text { média (phi) }\end{array}$ & Curtose & $\begin{array}{c}\text { Moda } \\
\text { (phi) }\end{array}$ & $\mathbf{n}$ \\
S1 & 6.07 & 2.08 & 0.34 & 2.50 & 6.15 & 7 \\
S2 & 5.84 & 2.28 & 0.29 & 2.45 & 4.74 & 6 \\
A1 & 3.41 & 1.94 & 1.31 & 5.00 & 2.26 & 20 \\
A2 & 4.45 & 1.98 & 1.21 & 4.56 & 2.84 & 7 \\
\hline
\end{tabular}

Tabela 2- Estatísticas descritivas dos dados granulométricos das fácies sedimentares descritas no TE.

\subsection{Geomorfologia das ilhas e interação com a vegetação ripariana}

O trecho onde situa-se o TE é um complexo de barras estabilizadas pela vegetação. As ilhas são compostas por terraços planos ou com depressões suaves e com solo predominantemente argiloso. As ilhas possuem margens em escarpas erosivas de até 2,5 metros de altura em relação ao nível d'água. As ilhas do TE são separadas por uma multiplicidade de canais sinuosos e comumente apresentam lagos ou canais internos.

Três tipos de vegetação ripariana foram observados nas porções marginais das barras e dos lagos internos (Figura 11a-c), os quais ocorrem de acordo com a seguinte sucessão:

- Nas margens das ilhas e nos lagos internos são comuns populações de capim Canarana (Echinochloa polystachya), uma das principais espécies pioneiras de terras inundáveis da amazônia (Camarão et al. 2006). Esta espécie atinge até 1 metro de altura.

-Populações de aningais, ou Aninga-açu (Montrichardia arborecens), espécie arbustiva que é também espécie pioneira de áreas inundáveis afetadas por maré (Carneiro 2012). Atingem até dois metros de altura e são comuns nas margens dos rios e igarapés. A presença dessa espécie indica influência de maré.

- Vegetação arbórea formada por Floresta de Ombrófilas Densas Aluviais (IBGE 2012), popularmente conhecidas como igapós, ocorrem no interior das 
ilhas. A ocorrência de espécies de floresta de ombrófilas indicariam processos de estabilização mais antigos.
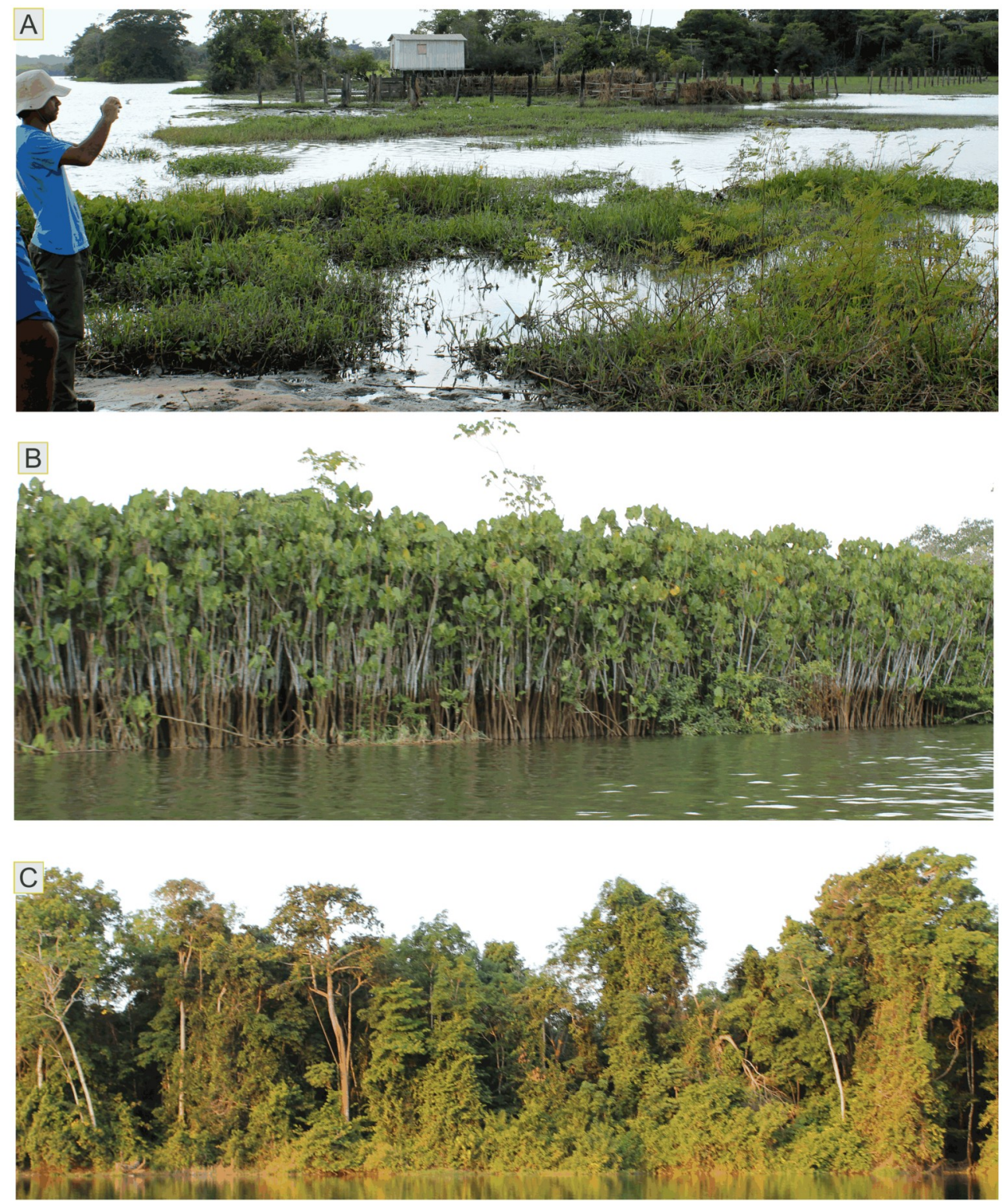

Figura 11. Sucessão da ocupação das barras do TE pela vegetação. A: Zona em processo de estabilização com crescimento de capim canarana (nordeste do TE). B: Vegetação arbustiva de Aninga-açu próxima à praia do Juncal. C: Vegetação arbórea de ombrófilas densa aluviais.

Foi observado que o capim canarana ocupa lagoas internas das ilhas e as margens externas, podendo ocupar totalmente o trecho de uma margem até outra de lagoa ou canal interno. A Canarana também flutua quando não há 
substrato, sendo capaz de se desprender da margem das ilhas e formar ilhas flutuantes que derivam (rafting) até encontrar outro substrato para colonização. A Figura 12 apresenta os estágios dos processos de estabilização de barras observados no TE.

Feições deposicionais ativas representadas por praias arenosas também foram identificadas. Barras arenosas de dezenas de metros de comprimento ocorrem nos pontais das ilhas e nas margens do canal. $O$ topo destas barras apresenta leito plano ou em dunas de menos de 0,5 metros de altura e até 3 metros de espaçamento entre as cristas (Figura 13). 

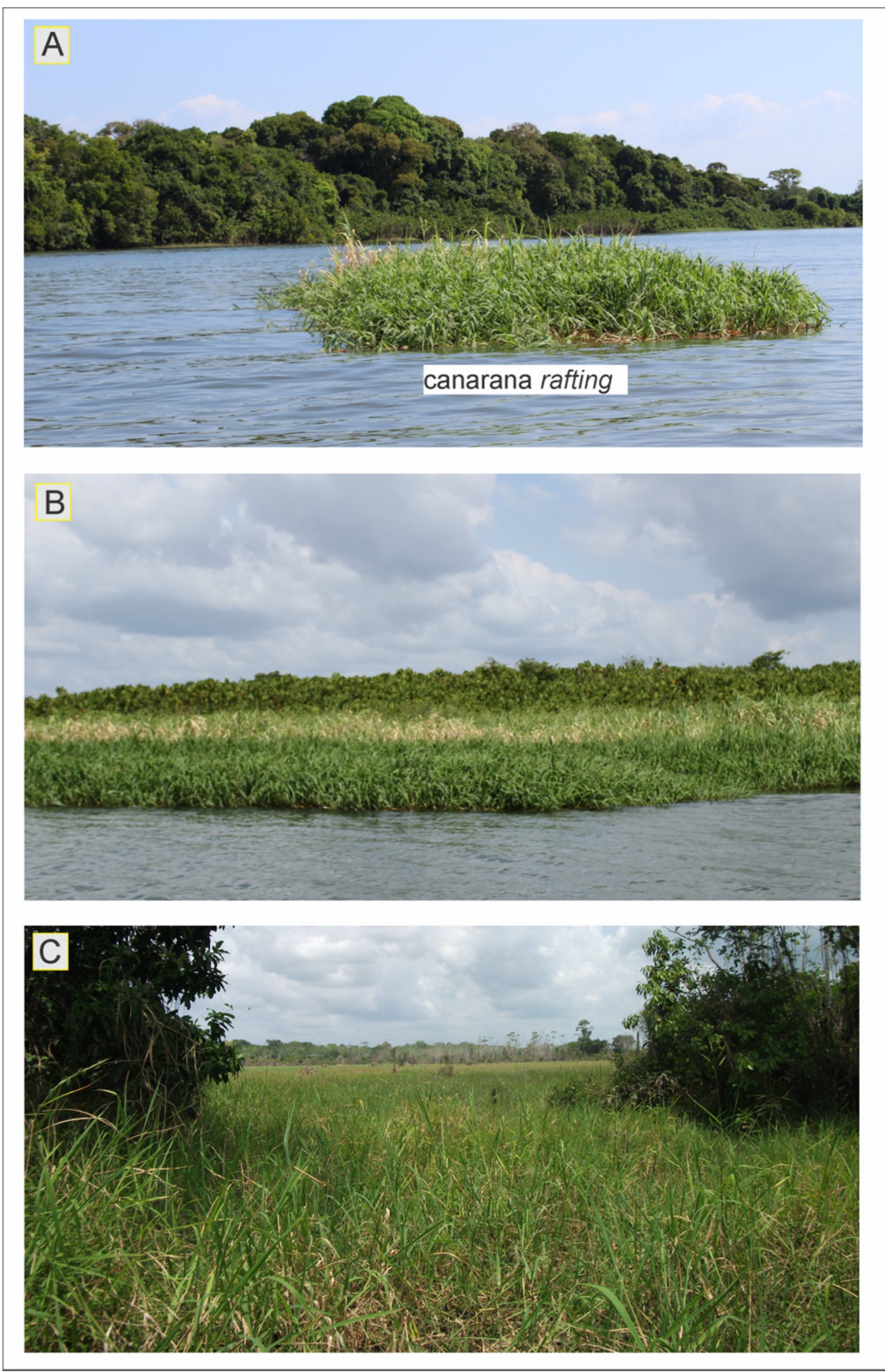

Figura 12 - Fixação da canarana às barras do TE. A: Rafting de Canarana, B: Fixação às margens e flutuação parcial, $C$ : área fixada pela vegetação, com desenvolvimento parcial de vegetação arbórea. 

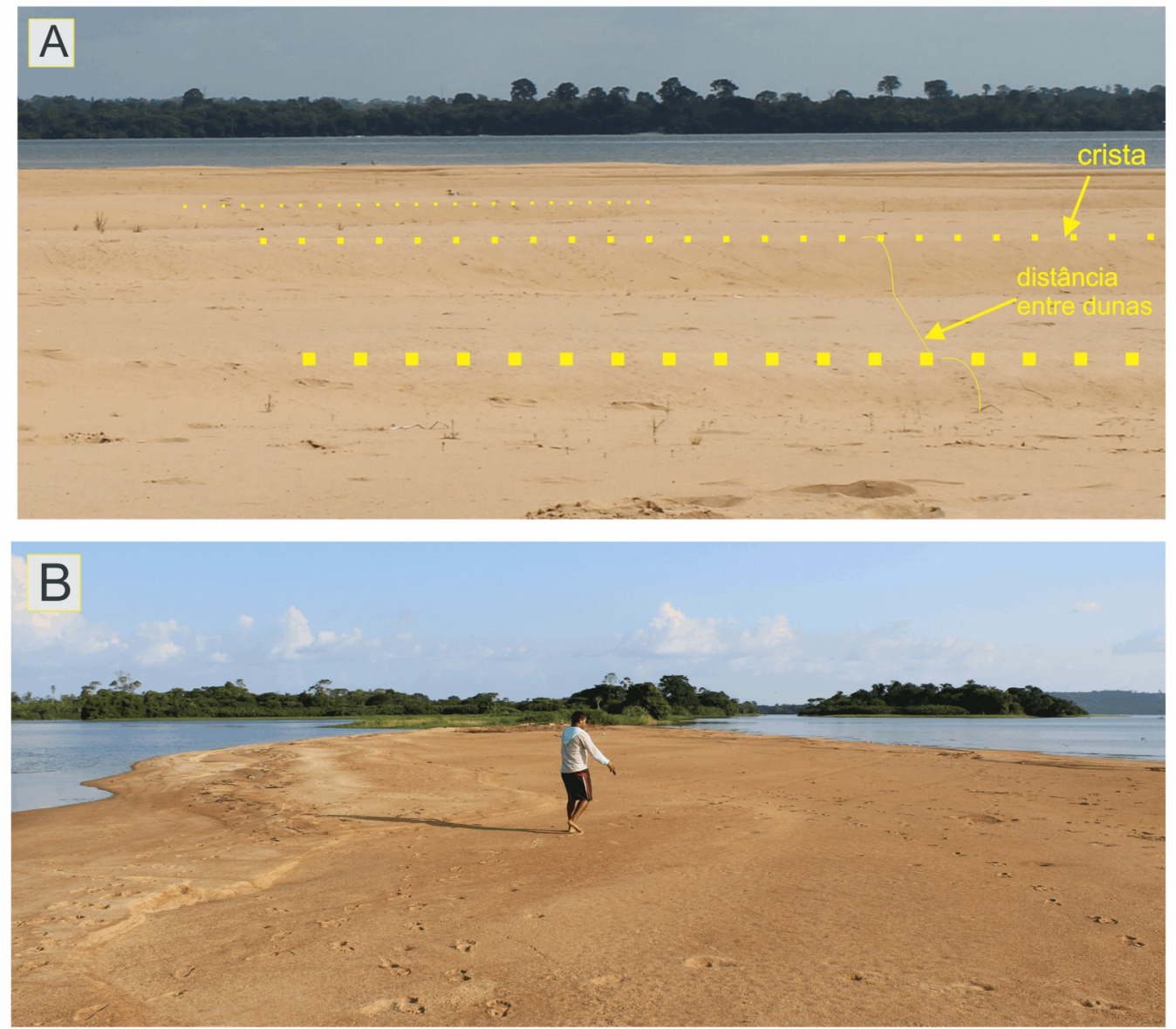

Figura 13 . Topos emersos de barras ativas (praias) observados em campo. A: Dunas formadas por deposição subaquosa em regime de fluxo inferior (vista frontal). B: Barra ativa de topo plano (regime de fluxo superior).

A Figura 14 apresenta o mapa geomorfológico, onde separou-se as feições deposicionais observadas no TE (cristas de barras fluviais, planícies de inundação e terraços elevados sem feições deposicionais aparentes). As margens das ilhas apresentam planícies mais rebaixadas que seu entorno e não ultrapassam 20 metros de altitude.

As estrutura das ilhas é constituída por barras alongadas fixadas pela vegetação em pelo menos uma das margens e com planícies de inundação em seu interior. Três unidades geomorfológicas distintas ( $A, B$ e $C$ ) foram identificadas de acordo com o grau de coalescência das barras que as compõem. 
A unidade $A$, da porção oeste do TE, representada pela maior ilha, é composta por barras amalgamadas, com área de $65 \mathrm{~km}^{2}$. As margens dessa ilha possuem vegetação arbórea, indicativa de estabilização mais antiga.

$A$ unidade $B$, da porção leste do TE, é representada por um conjunto de trinta ilhas, com barras estabilizadas segmentadas por diversos canais. Estas ilhas possuem áreas reduzidas (menor $11 \mathrm{~km}^{2}$ ) e barras de cristas mais estreitas alongadas por $1 \mathrm{a} 4 \mathrm{~km}$ de comprimento.

A unidade $C$ é constituída por barras de até $1 \mathrm{~km}$ de comprimento, com praias (topo de barras ativas) que se formam no período de estiagem e que não foram totalmente fixadas pela vegetação pioneira. Foi possível observar também topos de barras com formas de leito de regime de fluxo inferior, que quando afloram formam praias extensas.

A feição geomorfológica denominada "Terraço elevado" na margem direita do TE (cor lilás da Figura 14) possui cota de 25 a $50 \mathrm{~m}$ e possui topo acima dos níveis da variação anual do nível d'água do rio Xingu, sendo mais antiga que os terraços representados pelas unidades geomorfológicas A, B e C. O Terraço elevado encontra-se adjacente a áreas de Terra Firme, formadas por rochas sedimentares da Bacia do Amazonas.

O perfil P1-P2 (Figura 15) demonstra que as ilhas da unidade A possuem cotas próximas do nível d'água (entre 0 e $10 \mathrm{~m}$ ) e que há uma zona de depressão ao centro da unidade, enquanto as cotas das ilhas da unidade B são mais elevadas (entre 10 e $25 \mathrm{~m}$ ). 


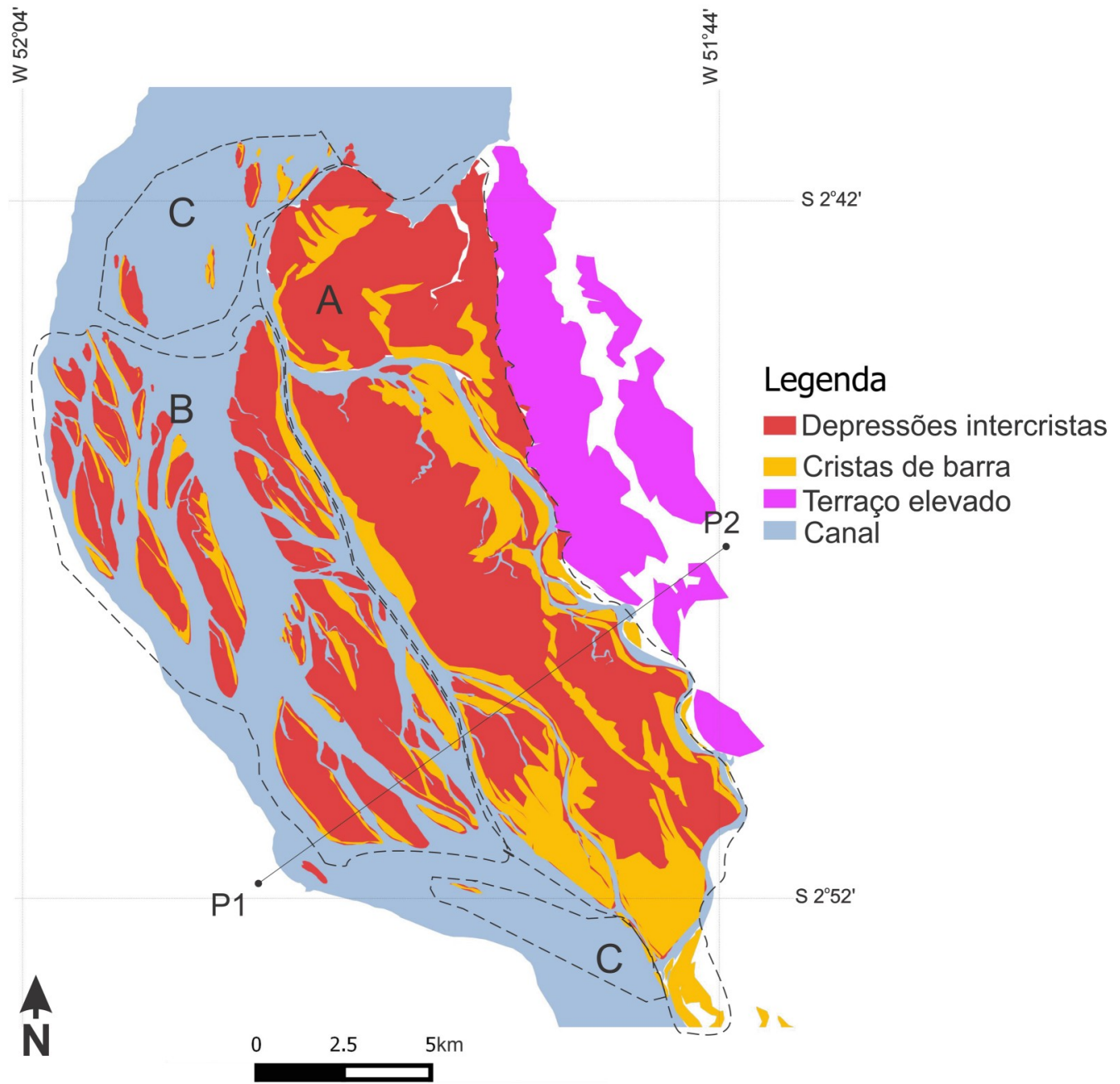

Figura 14. Mapa geomorfológico confeccionado a partir de produtos de sensoriamento remoto (Zona UTM 22s). Grupos de ilhas estão separados por linhas tracejadas: A - Grupo de ilhas leste, com uma ilha maior e grande planície de inundação e barras mais largas. B Grupo de ilhas a oeste formado por dezenas de ilhas menores, com predomínio de planícies de inundação e barras mais estreitas. C - Grupo de barras ativas, sujeitas a fixação pela vegetação, crescimento e erosão. A linha P1-P2 corresponde ao perfil da Figura 15. 


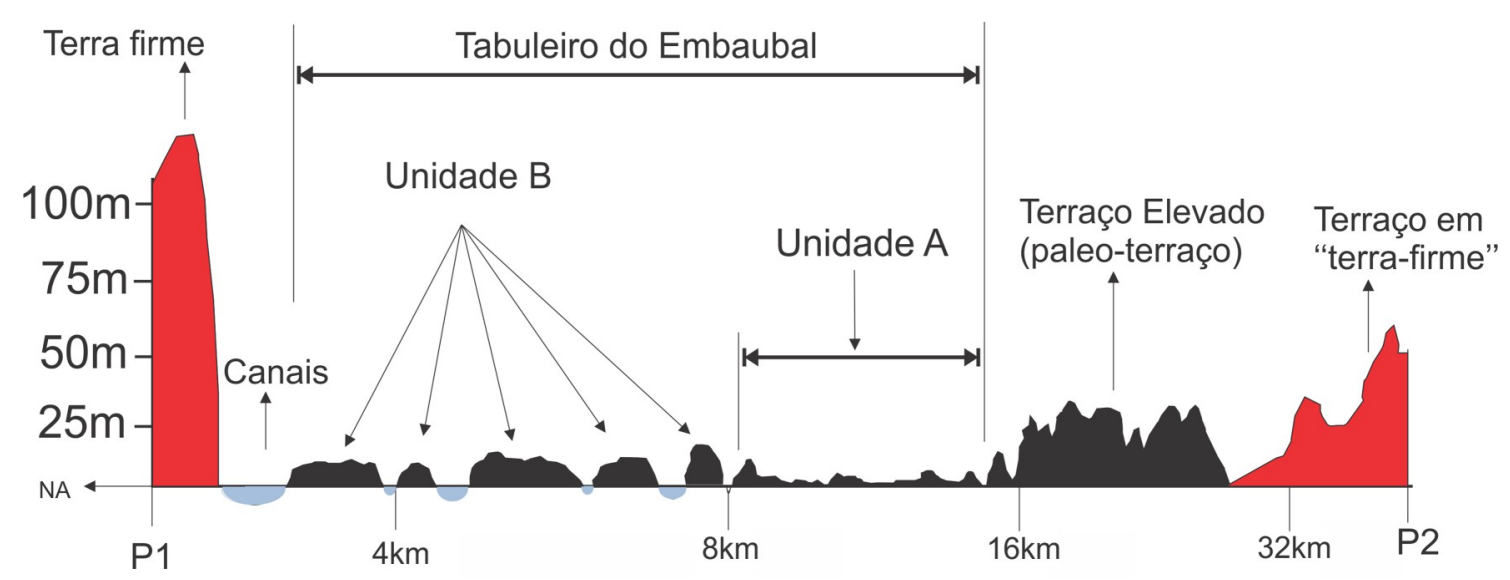

Figura 15- Perfil P1-P2 (ver localização na Figura 14) das unidades geomorfológicas da porção sul do TE. Exagero vertical de 25x. Perfil elaborado com o software Global Mapper.

\subsection{Cronologia de formação e estratigrafia das Ilhas}

As idades máxima e mínima obtidas para fácies arenosas (topo de barras) das unidades geomorfológicas do TE foram $10819 \pm 1043$ anos e $66 \pm 7$ anos, correspondendo aos pontos EMB13-02 e EMB13-05 (Figura 8), a 2,8 m e $0.3 \mathrm{~m}$ de profundidade, respectivamente. Ambos pontos estão situados no trecho sul do TE. As ilhas do unidade geomorfológica A teriam idades de estabilização entre $10819 \pm 1043$ e $66 \pm 7$ anos. A idade de $10819 \pm 1043$ anos pode corresponder a substrato erodido de terraço mais antigo, já que é de ocorrência local. Para a unidade geomorfológica $B$, as idades máxima e mínima foram $1096 \pm 71$ e $131 \pm 71$ anos, correspondentes aos pontos EMB13-19 e EMB13-17, a 1,2m e 0,35m de profundidade, respectivamente. Os resultados das idades OSL estão apresentados na Tabela 3. As idades OSL representariam os últimos eventos de movimentação das barras arenosas, anteriores ao recobrimento por vegetação.

As idades ${ }^{14} \mathrm{C}$ obtidas para fragmentos vegetais da fácies $\mathrm{S} 1$ estão apresentados na Tabela 4. Foram datadas 11 amostras pelo método ${ }^{14} \mathrm{C}$. Os resultados das análises encontram-se na Tabela 4. Para o unidade geomorfológica A, o intervalo de idades obtido para este método foi de 54795580 anos cal AP até 50-80 cal AP. Para a unidade geomorfológica $B, 0$ intervalo obtido foi de 730-741 anos cal AP até 499-505 anos cal AP. As idades 
da fácies S1 indicariam zona submersa permanente, corresponde à lagoas internas ou canal da ria.

A Figura 16 apresenta o mapa da distribuição dos pontos de coleta onde houve análises cronológicas e as idades obtidas em cada ponto.

A Figura 17 apresenta as seções colunares observadas na unidade geomorfológica A e a Figura 18 apresenta as seções colunares da unidade geomorfológica $\mathrm{B}$.

Os resultados indicam que há uma sucessão estratigráfica mais comum composta por uma camada de areia fina a média silto-argilosas (A1) na base com silte grosso arenoso (S2) no topo. Esta situação diferencia-se para sul da unidade geomorfológica $\mathrm{A}$, onde as fácies arenosas são frequentes no topo das seções colunares e onde há maior quantidade de feições de crista de barra preservadas (Figura 14).

A seção EMB13-07 registrou a maior espessura da fácies de silte médio argiloso orgânico (S1). Neste ponto, observa-se que 3 metros desta fácies foi depositado no intervalo de 5479-5580 anos cal AP até 4158-4234 anos cal AP. Este intervalo de tempo de deposição da fácies $\mathrm{S} 1$ pode representar a sedimentação em zona profunda da ria, em fase anterior à formação de planície de inundação do TE. Deste modo, a idade 4158-4234 anos cal AP indicaria a idade máxima para o TE nesta localidade.

Nas seções EMB13-13 e EMB13-17 (Figura 18), onde foram obtidas idade por ambos os métodos de geocronológicos, observou-se que as camadas da fácies silte grosso (S2) e das fácies arenosas (A1/A2) apresentaram idades mais recentes (invertidas) nas camadas inferiores. $\mathrm{Na}$ coluna EMB13-13, observou-se diferença de 200 anos entre a idade OSL (mais jovem) da fácies silte grosso arenoso (S2) e a idade ${ }^{14} \mathrm{C}$ da camada de silte argilo-arenoso orgânico (S1) do topo (mais velha). Na coluna EMB13-17, observa-se diferença de 23 anos entre a idade da fácies $\mathrm{S} 1$ da base e a fácies A1 do topo (mais velha). Estas inversões seriam aparentes, já que as idades estão sobrepostas pelos erros de datação. Isto sugere deposição rápida (acima 
da resolução dos métodos geocronológicos empregados) para os sedimentos destas seções. As demais seções com análises de ambos os métodos (EMB13-21 e EMB13-15) apresentaram concordância da estratigrafia com a cronologia.

Os maiores intervalos de tempo de deposição e as idades mais antigas ocorrem nas fácies arenosas das colunas EMB13-01, EMB13-02 e EMB13-03, no sul da unidade geomorfológica B. 


\begin{tabular}{|c|c|c|c|c|c|c|c|c|c|c|c|}
\hline Amostra & U (ppm) & Th (ppm) & $\mathrm{K}(\%)$ & $\left|\begin{array}{l}\text { Saturação } \\
\text { ém } \\
\text { água }\end{array}\right|$ & $\begin{array}{c}\text { Dose } \\
\text { equivalente }(G y)\end{array}$ & $\begin{array}{l}\text { Taxa } \\
\text { de dose } \\
\text { cósmica } \\
\text { (Gy/ka) }\end{array}$ & $\begin{array}{l}\text { Taxa de dose } \\
\text { total } \\
\text { (Gy/ka) }\end{array}$ & Idade (anos) & $\begin{array}{l}\text { Profundidade } \\
\text { de coleta }(m)\end{array}$ & $\mathrm{N}$ & $\mathrm{OD}(\%)$ \\
\hline EMB13-01A & $1.24 \pm 3.36 \mathrm{E}-05$ & $6.62 \pm 2.03 \mathrm{E}-04$ & $0.10 \pm 0.01$ & 0.16 & $7.51 \pm 0.73$ & 0.17 & $0.96 \pm 0.06$ & $7005 \pm 677$ & 0.5 & 13 & 24.8 \\
\hline EMB13-01B & $1.02 \pm 2.37 \mathrm{E}-05$ & $6.11 \pm 1.66 \mathrm{E}-04$ & $0.09 \pm 0.01$ & 0.15 & $17.97 \pm 1.36$ & 0.16 & $0.83 \pm 0.05$ & $19950 \pm 1616$ & 1.55 & 20 & 24.1 \\
\hline EMB13-02A & $0.96 \pm 2.40 \mathrm{E}-05$ & $3.94 \pm 9.74 \mathrm{E}-05$ & $0.07 \pm 0.01$ & 0.08 & $2.05 \pm 0.26$ & 0.17 & $0.70 \pm 0.04$ & $2340 \pm 249$ & 0.3 & 20 & 38.9 \\
\hline EMB13-02B & $0.92 \pm 2.16 \mathrm{E}-05$ & $6.10 \pm 1.73 \mathrm{E}-04$ & $0.10 \pm 0.01$ & 0.13 & $8.94 \pm 0.64$ & 0.16 & $0.84 \pm 0.05$ & $10819 \pm 1043$ & 0.9 & 17 & 30.1 \\
\hline EMB13-03 & $1.44 \pm 4.04 \mathrm{E}-05$ & $8.11 \pm 2.60 \mathrm{E}-04$ & $0.17 \pm 0.01$ & 0.08 & $103.84 \pm 5.03$ & 0.15 & $1.06 \pm 0.06$ & $90304 \pm 9365$ & 2.8 & 23 & - \\
\hline EMB13-05 & $3.26 \pm 1.81 \mathrm{E}-04$ & $11.11 \pm 5.17 \mathrm{E}-04$ & $0.58 \pm 0.03$ & 0.09 & $0.14 \pm 0.01$ & 0.17 & $2.06 \pm 0.14$ & $66 \pm 7$ & 0.3 & 16 & 30 \\
\hline EMB13-9A & $2.47 \pm 1.10 \mathrm{E}-04$ & $7.30 \pm 2.54 \mathrm{E}-04$ & $0.46 \pm 0.02$ & 0.17 & $0.43 \pm 0.03$ & 0.17 & $1.50 \pm 0.10$ & $289 \pm 26$ & 0.15 & 23 & 29.9 \\
\hline EMB13-9B & $1.61 \pm 5.00 \mathrm{E}-05$ & $5.10 \pm 1.41 \mathrm{E}-04$ & $0.40 \pm 0.02$ & 0.11 & $0.65 \pm 0.03$ & 0.17 & $1.25 \pm 0.09$ & $520 \pm 43$ & 0.3 & 21 & 16.6 \\
\hline EMB13-9C & $2.41 \pm 7.24 \mathrm{E}-05$ & $7.83 \pm 4.01 \mathrm{E}-04$ & $0.12 \pm 0.01$ & 0.15 & $1.17 \pm 0.04$ & 0.16 & $1.20 \pm 0.07$ & $977 \pm 66$ & 1 & 22 & 13.3 \\
\hline EMB13-11B & $0.72 \pm 1.40 \mathrm{E}-05$ & $3.50 \pm 7.08 \mathrm{E}-05$ & $0.17 \pm 0.01$ & 0.05 & $0.33 \pm 0.01$ & 0.16 & $0.66 \pm 0.04$ & $498 \pm 29$ & 0.72 & 23 & 5.5 \\
\hline EMB13-12 & $0.40 \pm 7.51 \mathrm{E}-06$ & $1.78 \pm 2.87 \mathrm{E}-05$ & $0.26 \pm 0.01$ & 0.18 & $0.23 \pm 0.02$ & 0.16 & $0.56 \pm 0.03$ & $405 \pm 36$ & 1.3 & 16 & 24.2 \\
\hline EMB13-13D & $1.69 \pm 5.46 \mathrm{E}-05$ & $5.57 \pm 1.61 \mathrm{E}-04$ & $0.39 \pm 0.02$ & 0.14 & $0.60 \pm 0.02$ & 0.15 & $1.01 \pm 0.05$ & $599 \pm 38$ & 3.3 & 22 & 12.8 \\
\hline EMB13-15B & $0.65 \pm 3.99 \mathrm{E}-05$ & $2.08 \pm 1.20 \mathrm{E}-04$ & $0.19 \pm 0.02$ & 0.32 & $0.11 \pm 0.01$ & 0.15 & $0.52 \pm 0.03$ & $194 \pm 12$ & 3 & 19 & 14.3 \\
\hline EMB13-16A & $1.35 \pm 4.01 \mathrm{E}-05$ & $5.05 \pm 1.40 \mathrm{E}-04$ & $0.39 \pm 0.02$ & 0.29 & $0.23 \pm 0.02$ & 0.17 & $1.10 \pm 0.07$ & $176 \pm 18$ & 0.35 & 17 & 29.6 \\
\hline EMB13-16B & $2.33 \pm 9.65 \mathrm{E}-05$ & $8.73 \pm 3.35 \mathrm{E}-04$ & $0.53 \pm 0.02$ & 0.12 & $0.87 \pm 0.03$ & 0.16 & $1.57 \pm 0.10$ & $553 \pm 41$ & 1.63 & 19 & 14 \\
\hline EMB13-17A & $1.99 \pm 7.07 \mathrm{E}-05$ & $6.77 \pm 2.03 \mathrm{E}-04$ & $0.43 \pm 0.02$ & 0.18 & $0.17 \pm 0.00$ & 0.17 & $1.31 \pm 0.08$ & $131 \pm 9$ & 0.35 & 21 & 10.2 \\
\hline EMB13-17B & $2.18 \pm 8.14 \mathrm{E}-05$ & $7.85 \pm 2.63 \mathrm{E}-04$ & $0.45 \pm 0.02$ & 0.18 & $0.47 \pm 0.01$ & 0.16 & $1.34 \pm 0.08$ & $348 \pm 23$ & 2.3 & 19 & 10.9 \\
\hline EMB13-18 & $1.19 \pm 6.85 \mathrm{E}-05$ & $3.52 \pm 2.42 \mathrm{E}-04$ & $0.35 \pm 0.02$ & 0.17 & $0.54 \pm 0.02$ & 0.16 & $0.77 \pm 0.05$ & $692 \pm 45$ & 2 & 21 & 11.8 \\
\hline EMB13-19 & $1.07 \pm 2.66 \mathrm{E}-05$ & $3.88 \pm 9.19 \mathrm{E}-05$ & $0.19 \pm 0.01$ & 0.14 & $0.85 \pm 0.02$ & 0.16 & $0.77 \pm 0.05$ & $1096 \pm 71$ & 1.2 & 16 & 9.1 \\
\hline EMB13-20 & $1.32 \pm 8.39 \mathrm{E}-05$ & $4.75 \pm 3.48 \mathrm{E}-04$ & $0.35 \pm 0.02$ & 0.15 & $0.80 \pm 0.01$ & 0.16 & $0.98 \pm 0.06$ & $817 \pm 51$ & 1.3 & 18 & 5.4 \\
\hline EMB13-21C & $0.90 \pm 2.00 \mathrm{E}-05$ & $3.17 \pm 6.69 \mathrm{E}-05$ & $0.25 \pm 0.01$ & 0.19 & $0.52 \pm 0.01$ & 0.15 & $0.68 \pm 0.04$ & $764 \pm 42$ & 3.3 & 19 & 5.6 \\
\hline EMB13-22 & $0.64 \pm 1.47 \mathrm{E}-05$ & $2.66 \pm 6.03 \mathrm{E}-05$ & $0.16 \pm 0.01$ & 0.25 & $0.30 \pm 0.01$ & 0.16 & $0.59 \pm 0.03$ & $505 \pm 33$ & 1.2 & 20 & 14.6 \\
\hline EMB13-23 & $0.63 \pm 1.33 \mathrm{E}-05$ & $2.22 \pm 4.26 \mathrm{E}-05$ & $0.38 \pm 0.02$ & 0.01 & $0.53 \pm 0.02$ & 0.17 & $0.85 \pm 0.06$ & $623 \pm 49$ & 1.4 & 22 & 13.1 \\
\hline
\end{tabular}

Tabela 3 - Resultados de datação por OSL, onde $\mathrm{N}$ é o número de alíquotas analisadas para cada amostra e O.D. (Overdispersion) é o índice de variabilidade estatística do CAM (Central Age Model). 


\begin{tabular}{l|c|c|c|c} 
Amostra & $\begin{array}{c}\text { Material } \\
\text { amostrado }\end{array}$ & $\begin{array}{c}\text { Prof. } \\
(\mathrm{m})\end{array}$ & $\begin{array}{c}\text { Idade convencional } \\
\text { (anos AP) }\end{array}$ & $\begin{array}{c}\text { Idade calibrada } \\
\text { (anos cal AP) }\end{array}$ \\
\hline EMB13-07A & folha & 210 & $3815 \pm 15$ & $4158-4234$ \\
EMB13-07B & folha & 303 & $3810 \pm 15$ & $4156-4232$ \\
EMB13-07C & folha & 373 & $3805 \pm 20$ & $4154-4228$ \\
EMB13-07D & folha & 458 & $3975 \pm 15$ & $4420-4437$ \\
EMB13-07E & folha & 532 & $4765 \pm 25$ & $5479-5580$ \\
EMB13-13B & galho & 210 & $765 \pm 15$ & $681-688$ \\
EMB13-13C & folha & 248 & $835 \pm 15$ & $730-741$ \\
EMB13-15A & folha & 278 & $65 \pm 15$ & $50-80$ \\
EMB13-17C & folha & 230 & $145 \pm 15$ & $141-267$ \\
EMB13-17D & galho & 240 & $360 \pm 20$ & $334-467$ \\
EMB13-21B & folha & 260 & $425 \pm 15$ & $499-505$
\end{tabular}

Tabela 4: resultados da datação por radiocabono pelo método AMS. 


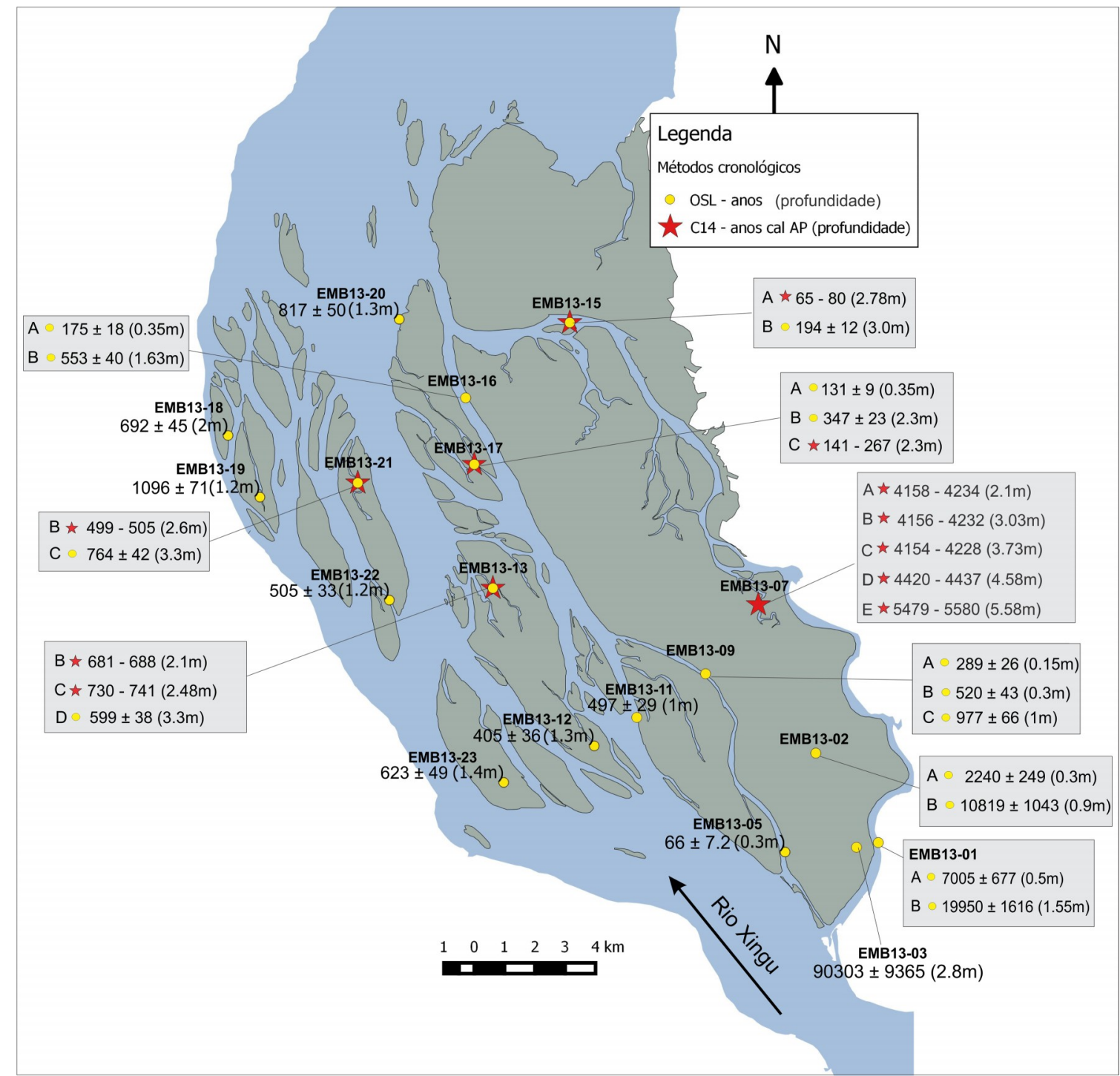

Figura 16 - Localização dos pontos amostrados para datações OSL e ${ }^{14} \mathrm{C}$ e idades obtidas. Os quadros apresentam as idades obtidas em profundidades diferentes do mesmo ponto. As letras A$E$ indicam amostras para o mesmo ponto. 


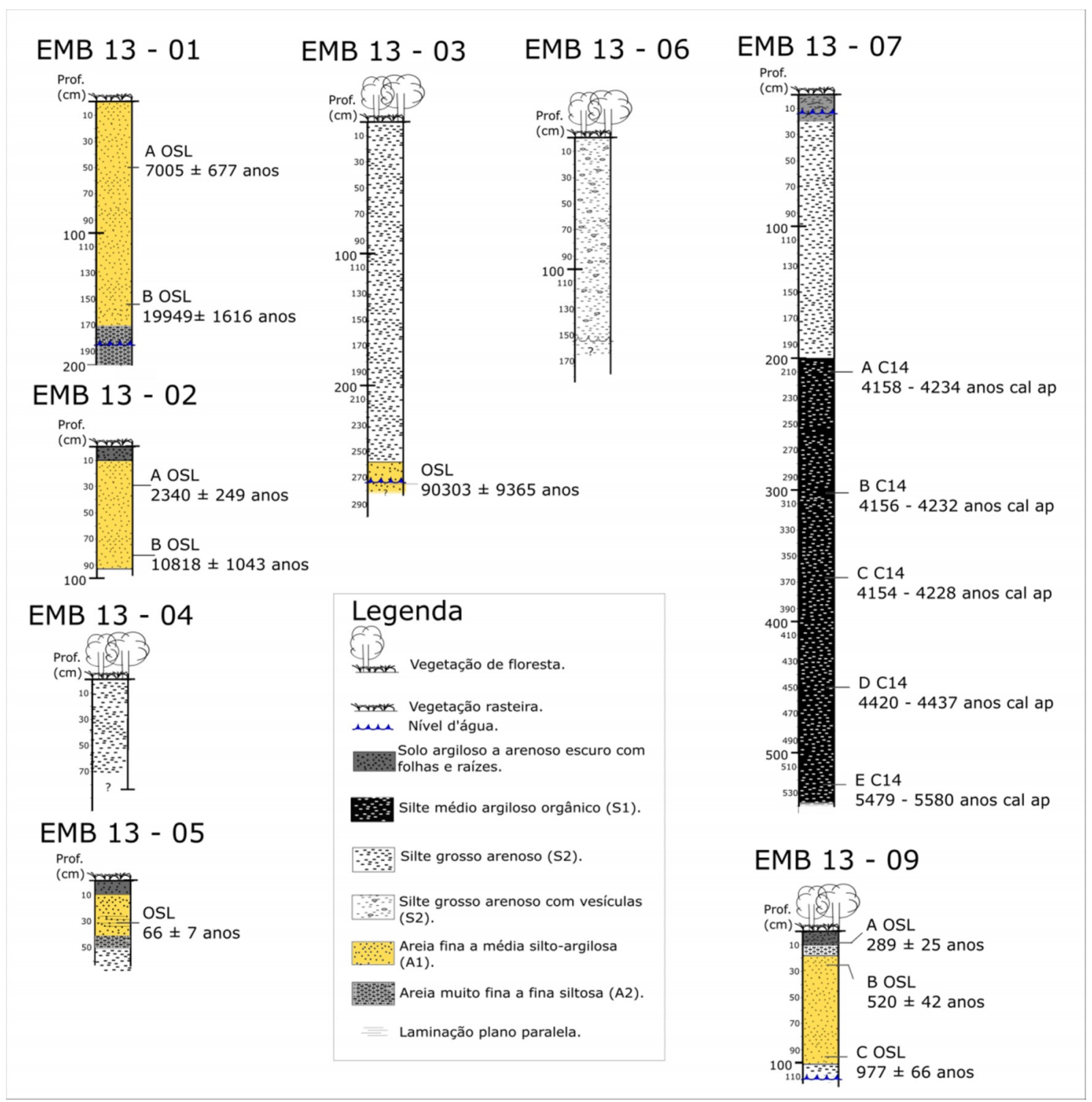

Figura 17 - Seções colunares do conjunto geomorfológico A com idades calculadas demarcadas nas profundidades observadas. 

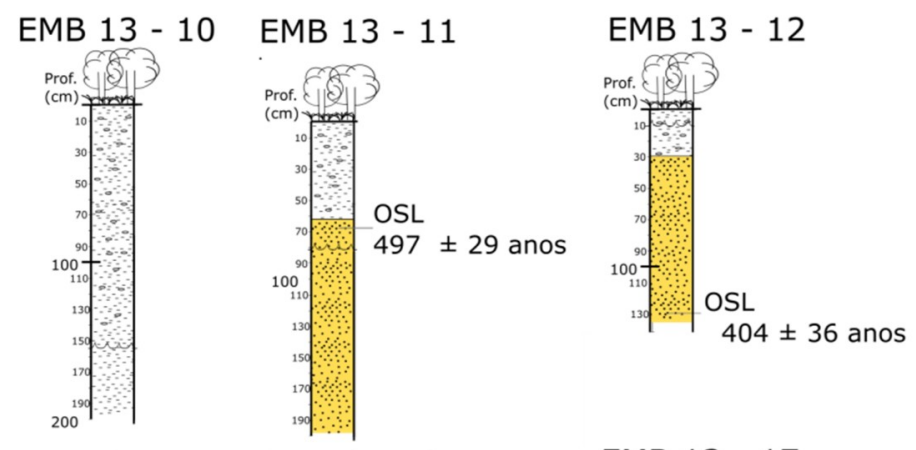

EMB $13-13$

\section{EMB $13-15$ EMB $13-16$}
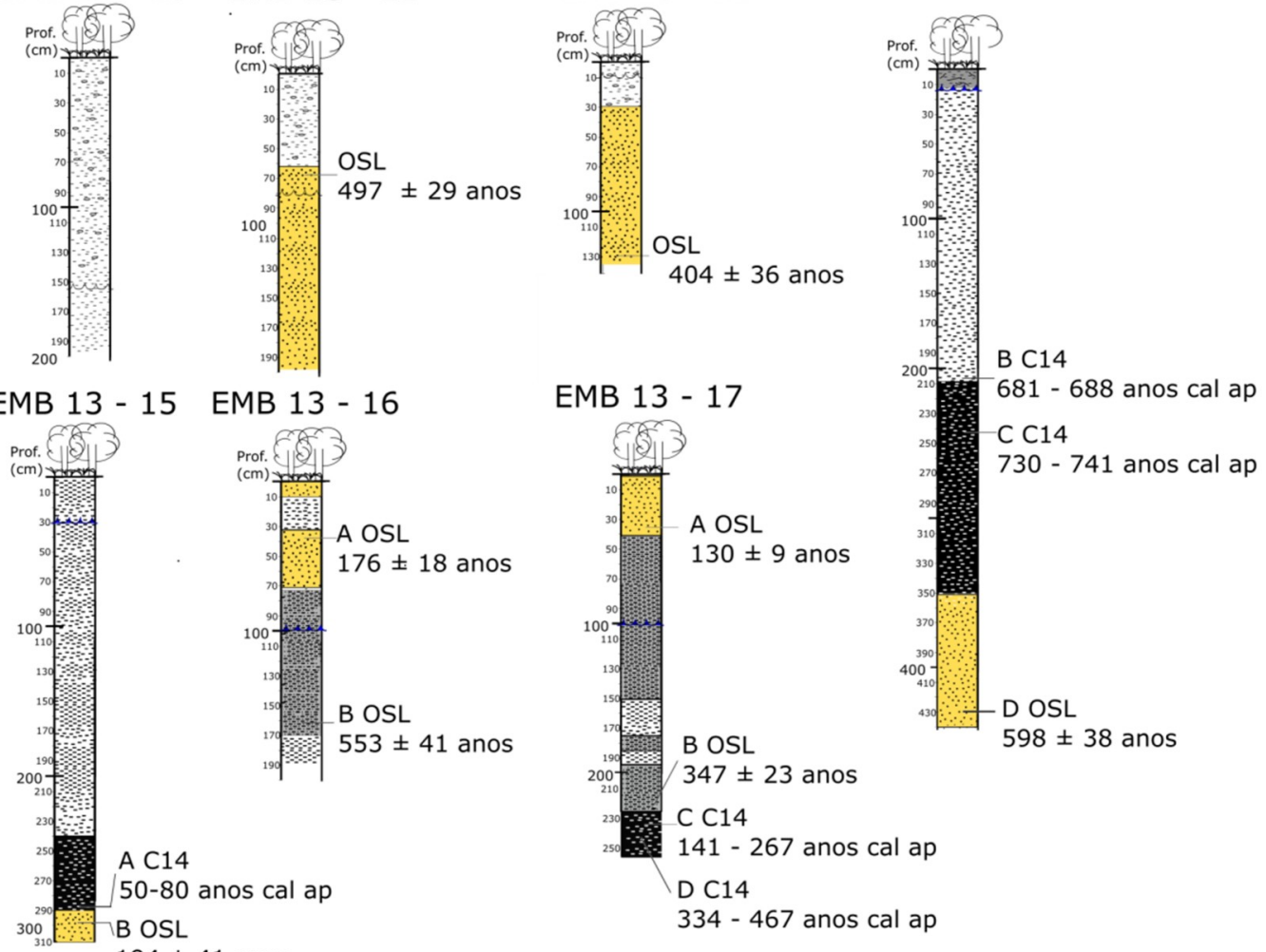

$553 \pm 41$ anos

$$
194 \pm 41 \text { anos }
$$

EMB $13-18 \quad$ EMB $13-19$

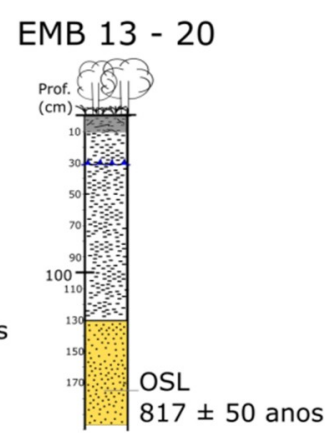

EMB $13-21$
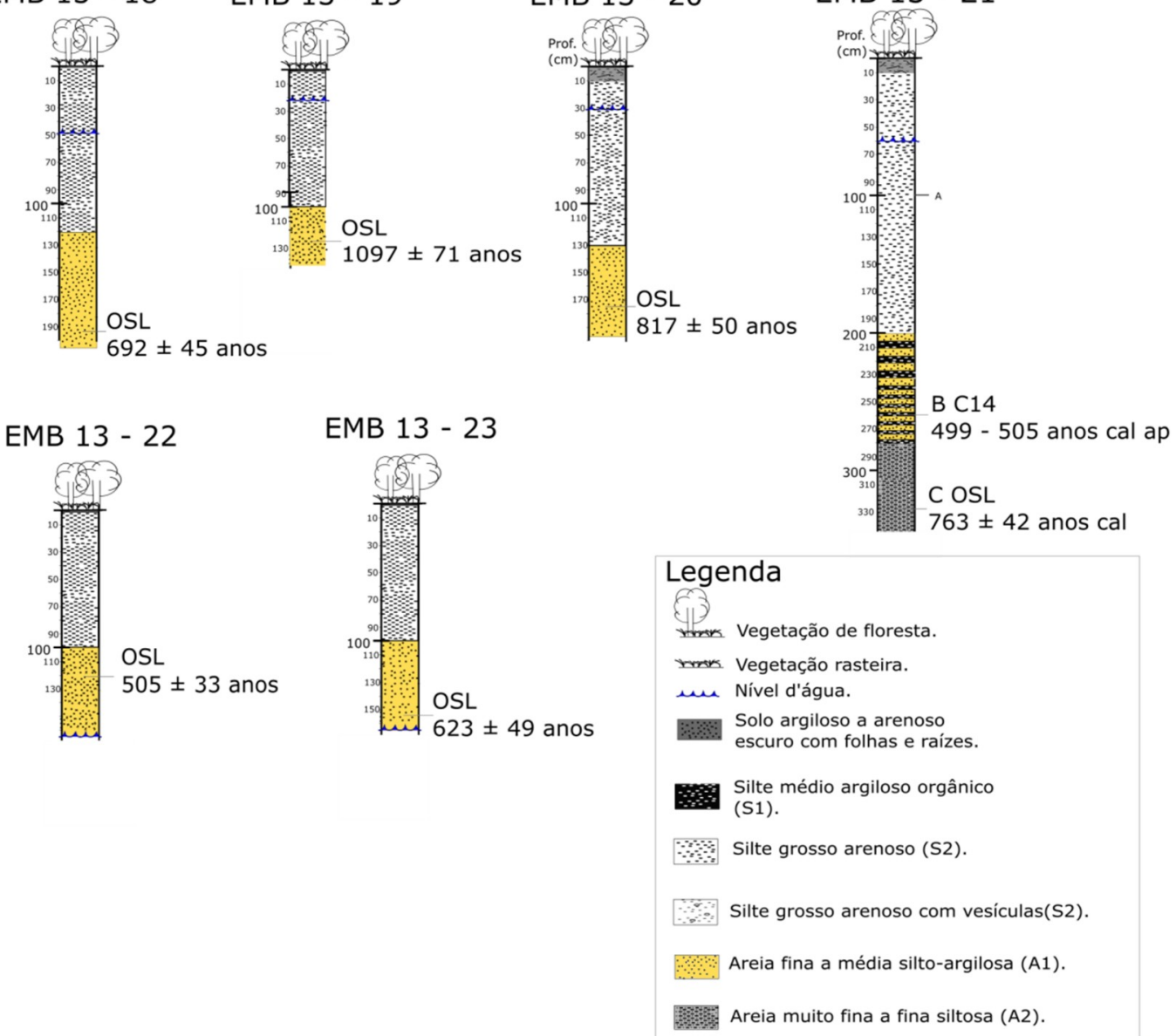

Figura 18 - Seções colunares da unidade geomorfológica B, com idades OSL e ${ }^{14} \mathrm{C}$ demarcadas nas profundidades observadas. 


\section{Discussão}

\subsection{Modelo deposicional}

Os resultados da análise de fácies sugerem que a organização estratigráfica mais comum dos depósitos que compõem as ilhas do TE é representada pela fácies de silte grosso arenoso (S2) no topo e pelas fácies areia (A1/A2) na base. A fácies silte médio argiloso orgânico (S1) ocasionalmente ocorre entre as fácies S2 e A1/A2.

As fácies de areia (A1/A2) representam depósitos de barras ativas, em fase anterior ao estabelecimento de vegetação para formação de ilha estável. Barras vegetadas estabilizadas também podem propiciar a acumulação de areia sob a forma de cristas alongadas no sentido da corrente. Deste modo, as barras podem apresentar diversas fases de crescimento seguidas de estabilização. Uma barra pode ser depositada ou acrescida num período de enchente e cheia, aflorando durante os períodos de vazante e seca e formando praias. As fácies arenosas quase sempre compõem a camada inferior do substrato das ilhas. A fácies A1 mais ocasional e seria resultante da transição gradual de barras ativas para planície de inundação vegetada.

As barras amalgamam-se com seu crescimento. Quando isto acontece, uma depressão alagada com fluxo d'água de baixa energia é criada entre as cristas das barras. Assim, o crescimento das barras pode formar lagos intercristas, com conexão restrita ao canal principal do rio Xingu. A zona alagada entre as cristas tem regime deposicional de lago, o qual é circundado por barras vegetadas ou planície de inundação, caso tenha respectivamente substrato submerso ou emerso durante a estação seca. Tais ambientes possuem áreas inundáveis de baixa energia favoráveis à deposição de sedimentos finos (silte a argila). Além disso, a deposição de silte e argila é acentuada na presença da vegetação pioneira, que é adaptada a alagamentos e também reduz a energia da corrente. A coloração cinza-claro da fácies S2 denota alta oxidação no ambiente deposicional, indicando que são áreas alagadas conectadas ao rio, porém com exposição subaérea regular. Os lagos internos perenes (Figura 17), cujas águas têm conexão restrita com o canal 
principal do rio, resultam num ambiente de baixa oxidação. A esse ambiente de deposição associou-se os depósitos de silte argiloso orgânico (S1), pois sua coloração cinza escuro e elevada quantidade de detritos vegetais indica baixa oxidação e presevação da matéria orgânica. Assim, a fácies S1 representaria deposição de sedimentos finos em lago perene, o que inibiria a oxidação da matéria orgânica vegetal.

Desta forma, tem-se a seguinte interpretação genética para a associação faciológica do TE:

- Fácies S1: lago perene interno ou centro do canal da ria, com deposição de lama e preservação de matéria orgânica sob condições de baixa oxigenação das águas de fundo.

- Fácies S2: planície de inundação, com exposição subaérea regular devido ao elevado grau de oxidação da lama.

- Fácies A1: base ou meio de barra arenosa ativa.

- Fácies A2: topo de base arenosa ativa.

A Figura 19 apresenta as fases de formação das ilhas do TE. O topo de barra arenosa emersa pode ser fixado pela vegetação durante o período de seca e proteger a barra dos processos erosivos e migração em cheias posteriores. $\mathrm{O}$ assoreamento progressivo dos lagos internos gera planícies de inundação e proporciona a transição entre as fácies S1 e S2. A emersão da área assoreada facilita o estabelecimento de vegetação arbórea e formação de floresta de igapó sobre solo argiloso. 


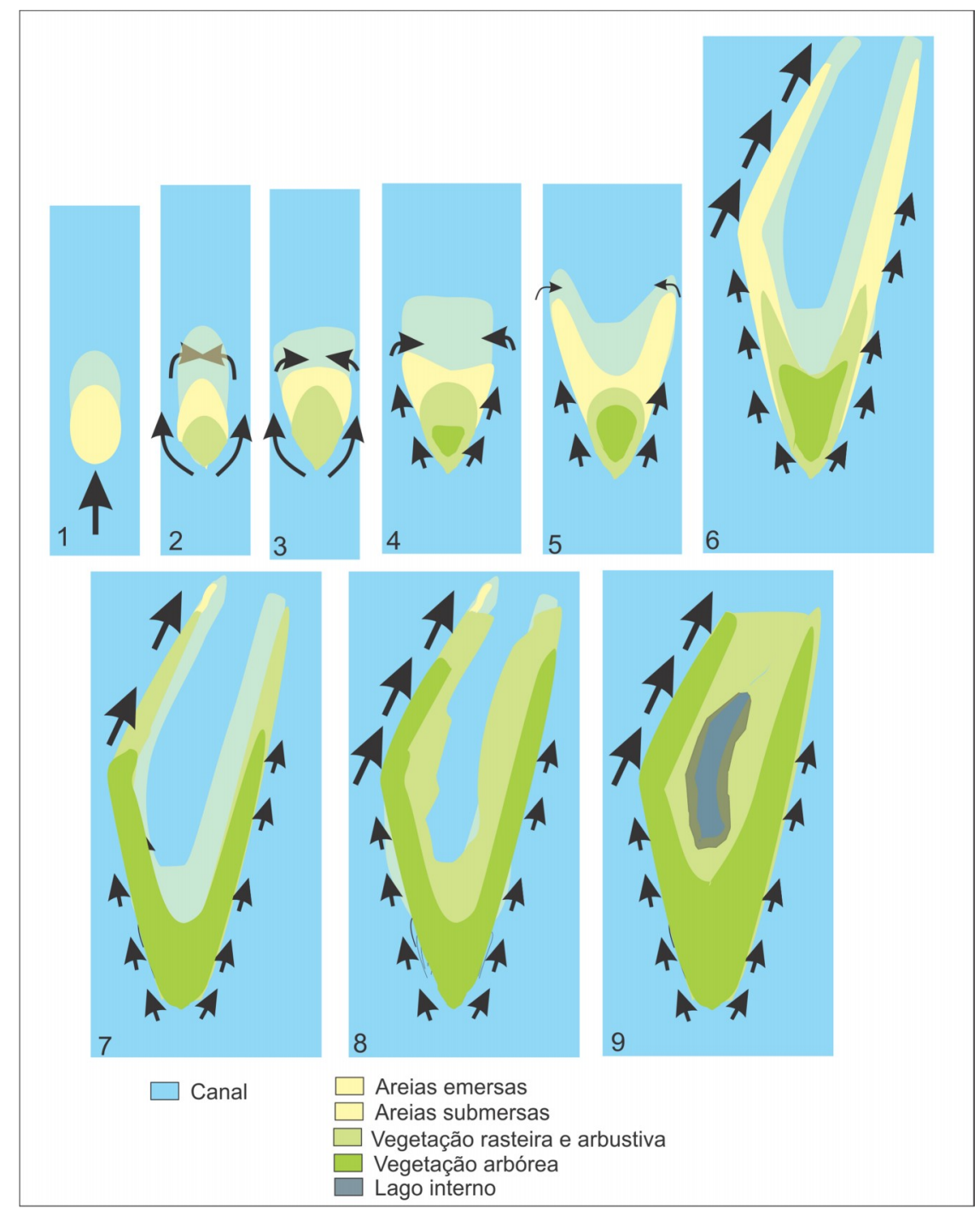

Figura 19 - Modelo para a formação de ilha no Tabuleiro do Embaubal. Representação vista em planta, com formação de lago interno e colonização das cristas das barras por vegetação. As setas indicam o sentido do fluxo do rio. As fases 1 a 6 representam a deposição da barra arenosa, seu prolongamento para jusante e colonização pela vegetação. As fases 7 a 8 representam a formação de lago interno com conexão restrita ao canal. 


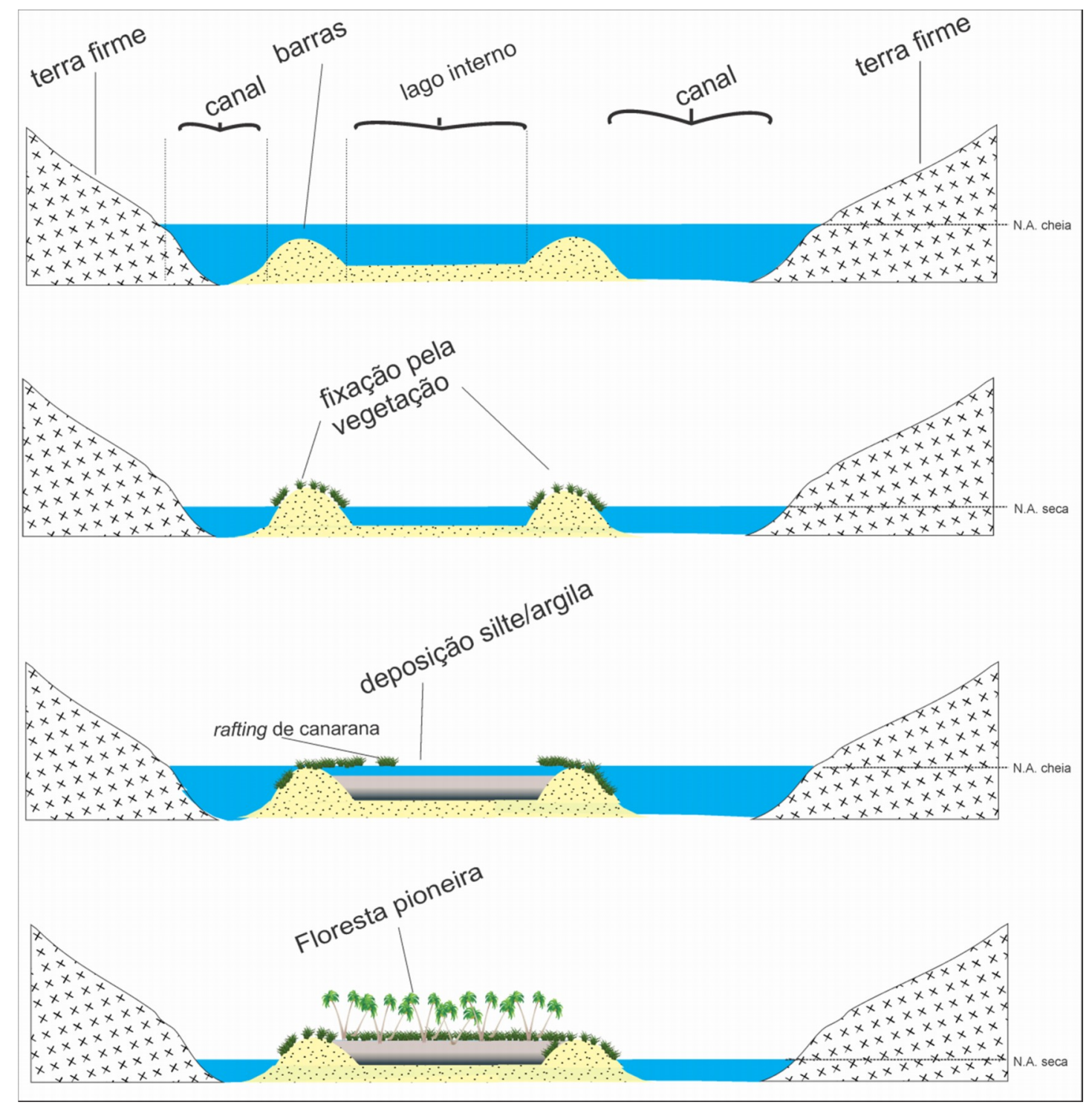

Figura 20- Modelo deposicional para a formação das ilhas do Tabuleiro do Embaubal por meio do assoreamento de um lago interno.

A maioria das seções colunares descritas indicaram que o substrato das ilhas é formado por fácies arenosas (A1/A2) na base recobertas por fácies siltosas (S1/S2). A recorrência das camadas arenosas sobre fácies siltosas foi observada apenas nas colunas descritas nos pontos EMB13-05, EMB13-06 e EMB13-17. Isto sugere certa estabilidade das barras colonizadas por vegetação. As idades OSL obtidas indicam que as barras estabilizadas podem permanecer estáveis por centenas a alguns milhares de anos, tal como indicado pelas idades de deposição obtidas nas unidades geomorfológicas A e B. Contudo, a maioria das barras estabilizadas apresenta escarpas verticais indicativas de processos erosivos recentes. Assim, apesar da tendência de 
crescimento do TE, processos erosivos recentes ocorrem nas margens das barras estabilizadas. A erosão das barras estabilizadas resultaria da variação do nível d'água entre as estações seca e chuvosa.

O processo de rafting da canarana e sua atuação na fixação do topo das barras ocorre de forma relativamente rápida. Idades OSL indicam que o recobrimento de barras arenosas por vegetação arbórea pode ocorrer em poucas centenas anos. $\mathrm{Na}$ ausência de processos erosivos, a vegetação aprisiona a areia depositada pelas barras, privilegiando a deposição das fácies A2 e S2. Isso faz com que novas áreas de deposição se formem à jusante do canal. O compartimento $C$ do mapa geomorfológico (Figura 14) corresponde a essas novas áreas, onde deposição de novas barras está ativa. Dessa forma a manutenção e crescimento do Tabuleiro do Embaubal depende do aporte sedimentar sazonal das regiões de montante. Segundo Mineli (2013), a maior parte do aporte de areia para a região do Tabuleiro do Embaubal seria derivada de setores a montante da Volta Grande do Xingu.

Perfis batimétricos (Norte Energia 2011) indicam baixa profundidade dos canais entre as ilhas do TE, com extensas áreas rasas que não ultrapassam 10 metros de profundidade e um canal principal situado predominantemente na margem esquerda do rio Xingu e que secciona as unidades geomorfológicas $B$ e C (Figura 14 e Figura 22).

Depósitos de barras comumente apresentam retrabalhamento sedimentar com erosão à monte e deposição à jusante das barras. No entanto, interpretase que somente as seções colunares dos pontos EMB13-05, EMB13-16 e EMB13-17 registraram episódios de reativação de barras arenosas sobre planície de inundação. Quase a totalidade das seções colunares registrou estabilidade e continuidade no processo de assoreamento dos lagos internos e formação de ilhas. Os resultados deste estudo indicam que o processo de estabilização do TE predomina sobre a migração de barras ativas com topo emerso, sendo esta uma zona de retenção de sedimentos enquanto que a Volta Grande seria zona de transferência de sedimentos, tal como proposto em Mineli (2013). 
Nesse contexto, as idades observadas indicam que o processo de estabilização e crescimento da vegetação arbórea sobre barras ocorre em intervalos de tempo de escala secular, sendo cerca de 130 anos a idade mínima obtida para a fácies arenosa de barra recoberta por vegetação arbórea.
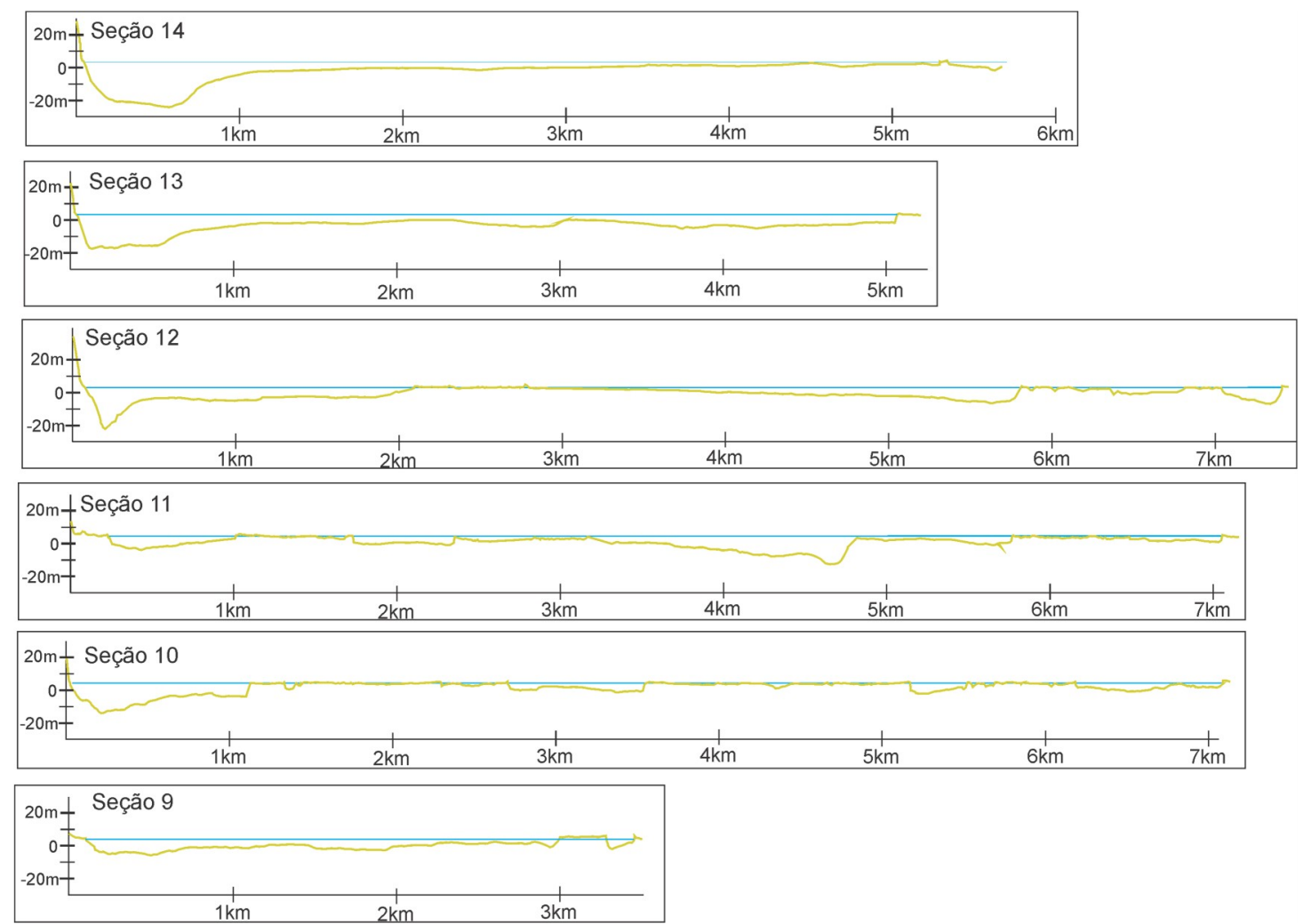

Figura 21 - Perfis batimétricos transversais aos canais do Tabuleiro do Embaubal. Dados obtidos para o plano básico ambiental de Belo Monte em 11 de Março de 2011 (Norte Energia 2011). 


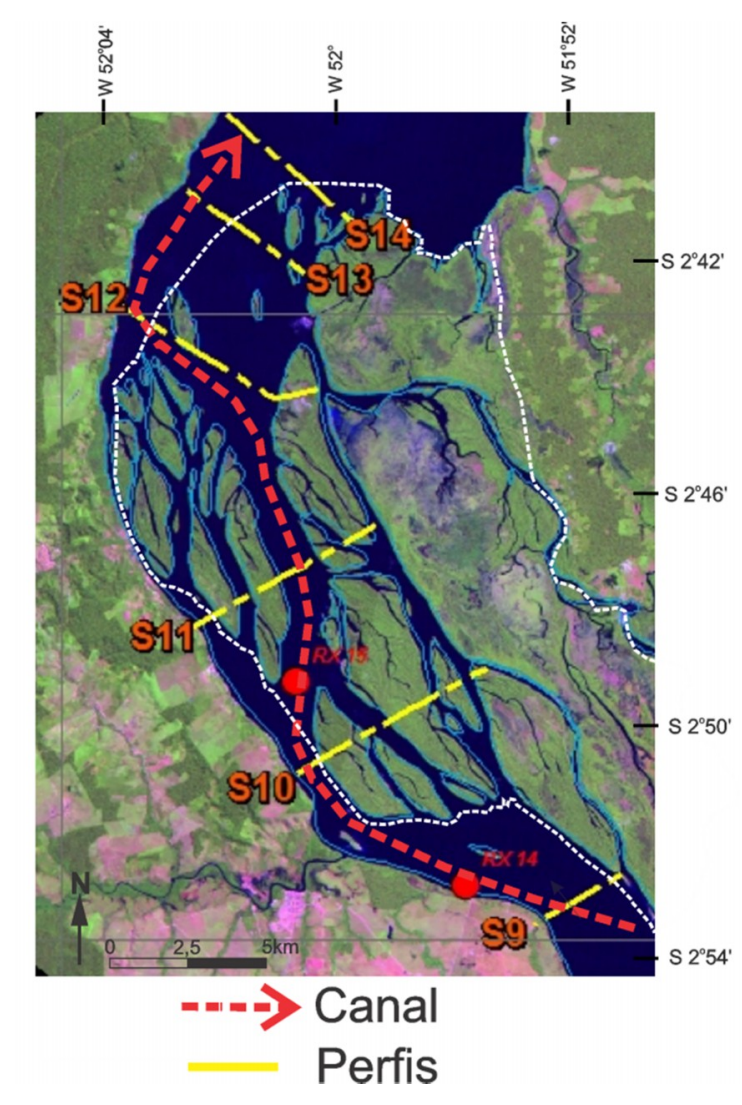

Figura 22 - Localização dos perfis batimétricos e traçado do canal principal do rio Xingu. Modificado de Norte Energia (2011).

\subsection{A formação das ilhas e variações de precipitação durante o Holoceno}

O principal fator que privilegia a intensificação do aporte de sedimentos arenosos responsáveis pela deposição das barras na cabeceira da ria do Xingu seria a variação da precipitação na bacia do rio Xingu. A precipitação controla os eventos erosivos das margens do canal e a carga de areia que chega até a cabeceira da ria do rio Xingu, onde se desenvolve o TE. Além disto, eventos extremos de precipitação podem gerar barras mais elevadas devido ao maior acréscimo vertical de sedimentos durante a fase de enchente. Isto favoreceria a posterior formação de barras estabilizadas (ilhas), já que o topo das barras podem formar substratos emersos mesmo em eventos de cheias seguintes. A presença de vegetação também exerce influência significante, pois estabiliza as margens e dificulta processos erosivos. Neste caso, variações de precipitação de longa duração, capazes de modificar a densidade da cobertura vegetal, podem induzir aumento do escoamento superficial e, 
consequentemente, do aporte sedimentar, caso exista redução da densidade de vegetação (Stickler et al. 2013).

Dois cenários climáticos são observados ao longo da bacia do rio Xingu. Estes cenários são definidos por variações de precipitação ligadas à SACZ (South Atlantic Convergence Zone) e ITCZ (Intrertropical Convergence Zone). A zona da cabeceira do rio Xingu na região central do Brasil, com maior influência da SACZ, atualmente atinge os maiores índices de pluviosidade da bacia (Figura 4). O médio e baixo curso do rio Xingu pertence ao contexto climático do leste da Amazônia e possui pluviosidade regional associada a influência direta da ITCZ. Segundo Cheng et al. (2013), o leste da Amazônia apresenta variação de precipitação inversa ao restante das áreas mais afetadas pela SACZ, que controla a pluviosidade na maior parte do Brasil e que está em fase com o nordeste do Brasil devido ao SAPD (South American Precipitation Dipole). Contudo, a captação de água para a bacia do Xingu ocorre principalmente nas áreas de cabeceira, de modo que variações na SACZ exerceriam maior efeito sobre a vazão e nível do rio Xingu.

A precipitação na cabeceira do rio Xingu durante o Holoceno foi influenciada principalmente pela formação do SAMS (South American Monsoon System), cujas variações de escala secular são influenciadas principalmente pela formação da SACZ. Registros de espeleotemas da América do Sul indicam que a atividade do SAMS era pouco expressiva durante o início do Holoceno até o Holoceno médio (Vuille et al. 2012).

Três episódios climáticos globais de escala secular do Holoceno tardio merecem destaque considerando as idades obtidas para a formação da porção noroeste do Tabuleiro do Embaubal (1096 \pm 71 a $131 \pm 71$ anos). Estes episódios são representados pela Anomalia Quente Medieval (MWA, Medieval Warm Anomaly), Pequena Idade do Gelo (LIA, Little Ice Age) e o Período Quente Atual (CWP, Current Warm Period).

A MWA é uma anomalia positiva da temperatura global, que perdurou desde 900 DC até 1250 DC (1050 AP até 700 AP) (Hughes \& Diaz 1994). A LIA é uma anomalia negativa na temperatura global que perdurou desde $1650 \mathrm{DC}$ 
até $1850 \mathrm{DC}$ (300 AP até $100 \mathrm{AP})$ (Matthews \& Briffa 2005) enquanto que o CWP representa uma anomalia positiva que ocorre de $1900 \mathrm{DC}$ até o presente (Vuille et al. 2012).

Vuille et al. (2012) através de modelos baseados em indicadores de precipitação em espeleotemas estabeleceram um índice para a formação de monções na América do Sul durante os últimos 2000 anos. Durante os períodos MWA e CWP, estes autores sugerem que ocorrência de SAMS foi enfraquecida devido ao deslocamento da ITCZ para norte. Durante a LIA, teria ocorrido o deslocamento da ITCZ para sul e o fortalecimento do SAMS.

Os dados geocronológicos obtidos para o TE indicam que houve intenso período de formação de barras na unidade geomorfológica $B$ a partir dos últimos 1100 anos. Este período coincide aproximadamente com o início do MWA e perdura até os dias atuais (Figura 23). Contudo, nota-se também que das idades 24 idades obtidas para fácies arenosas neste período, 19 estão situadas dentro do intervalo da LIA. Isto sugere que a formação das ilhas do TE está associada ao fortalecimento seguido de enfraquecimento do SAMS respectivamente durante a LIA e CWP (Vuille et al. 2012). 


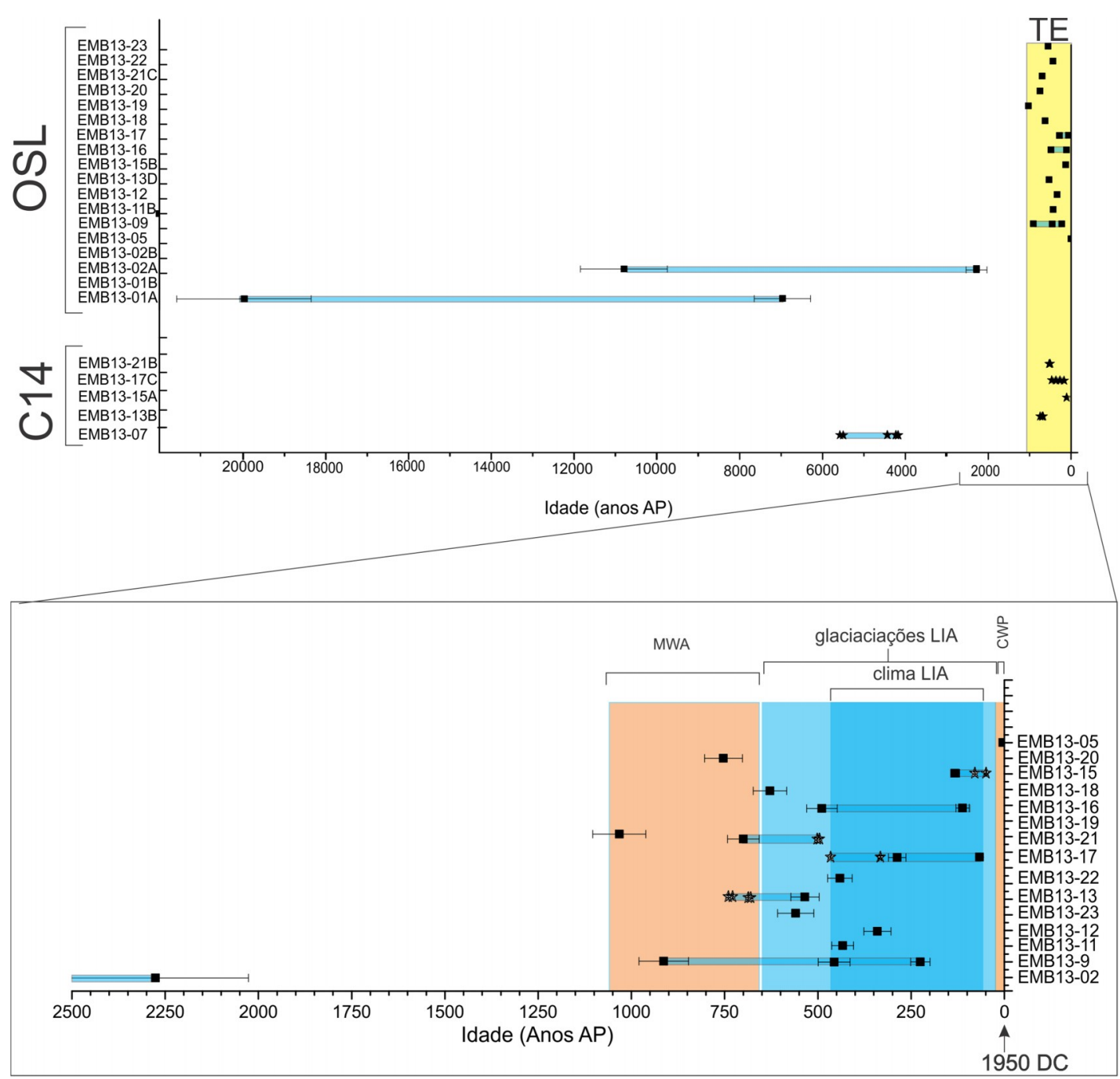

Figura 23 - Intervalo de tempo das idades OSL (quadrados) e ${ }^{14} \mathrm{C}$ (estrelas) obtidas para as ilhas da porção noroeste do TE (unidade geomorfológica B). As faixas azuis indicam intervalos de deposição no mesmo perfil estratigráfico.

Com relação ao cenário do médio e baixo Xingu, segundo Cheng et al. (2013), o período mais recente de alta precipitação para o leste da Amazônia e nordeste do Brasil deve ter ocorrido durante o início do Holoceno até o fim do Holoceno médio, entre 11000 anos AP e 4000 anos AP. Este evento pode estar associados à formação do trecho sul do conjunto geomorfológico $A$ do TE, onde duas idades OSL obtidas correspondem a esse intervalo (EMB13-01A e EMB13-02B). No entanto, esses locais apresentaram taxa de sedimentação inferior aos demais locais e o intervalo de deposição das barras (idades do topo e da base) extrapola esse período. Dessa forma, as idades obtidas nesse intervalo não sugerem que o regime climático do leste amazônico controle a sedimentação do TE. 


\subsection{Evolução sedimentar do Tabuleiro do Embaubal}

A morfologia do canal principal, com zona mais profunda a oeste, e as idades de deposição obtidas, que indicam ilhas mais jovens a oeste, sugerem que o canal principal do rio Xingu na cabeceira da ria tornou-se mais largo com a erosão da margem esquerda. O complexo de ilhas do TE representaria a margem interna deposicional com crescimento lateral para oeste e a jusante para norte. A ocorrência das falésias na margem esquerda da ria do Xingu deve resultar da maior susceptibilidade desta margem à erosão provocada por ondulações formadas por ventos de $\mathrm{NE}$, os quais predominam na área de estudo. A margem direita, mais protegida da erosão por ondas, é constituída por paleoterraços vegetados (Figura 14).

Sedimentos fluviais anteriores ao Holoceno médio na região do TE são descontínuos. Isto sugere cenário mais antigo (anterior a 5 mil anos atrás) com predomínio de erosão e aporte sedimentar reduzido. Apartir dos últimos 5 mil anos haveria aumento do nível d'água no canal (formação da ria?) e, intensifica-se os processos erosivos da margem esquerda. A elevação do nível d'água e alargamento do canal principal favoreceria a acumulação de sedimentos e a progradação de complexos de barras para oeste e para jusante. Com a ativação do SAMS há 2000 anos, o aporte sedimentar intensifica-se rapidamente e diversas barras são depositadas e fixadas pela vegetação. Durante o CWP, ocorre gradual enfraquecimento do sistema de monções. Nesse período, depositam-se as barras no norte do TE (unidade geomorfológica $C$ da Figura 14), mas em frequência reduzida. Esses resultados sugerem que a precipitação ligada ao SAMS é a principal forçante dos processos deposicionais responsáveis pela formação das ilhas do TE e que estes processos permanecem ativos porém enfraqueceram nos últimos 100 anos. 


\subsection{Possíveis mudanças no Tabuleiro do Embaubal resultantes das barragens do Empreendimento Hidrelétrico de Belo Monte}

Diversos trabalhos têm discutido os impactos que barragens provocam em rios (Rosenberg et al. 1997, Nilsson \& Berggren 2000, Fearnside 2001 2006, Yang et al. 2006). Quando nos referimos a ambientes amazônicos, os impactos provocados por barragens se tornam mais preocupantes, pois não existem ambientes tropicais de dimensão e características análogas na Terra.

Com base nos dados obtidos neste estudo, mudanças no Tabuleiro do Embaubal podem ser discutidas na intenção de se prever cenários futuros resultantes de intervenções antrópicas, tais como a implantação de barragens. Com a presença das barragens do Empreendimento Hidrelétrico de Belo Monte, o barramento da calha principal do rio Xingu associado à redução da vazão à jusante reduzirá a transferência de areia ao longo da Volta Grande do Xingu, visto que o transporte de areia no rio Xingu é dominado pela carga de fundo. Isto poderá afetar a dinâmica de crescimento secular a milenar do Tabuleiro do Embaubal e intensificar a deposição de sedimentos finos (silte e argila em suspensão). Dessa forma, as praias do TE poderão ter maior dificuldade de formação, pois terão aporte de areia reduzido e ficarão mais tempo expostas para recobrimento pela vegetação. A redução da variabilidade da vazão do rio Xingu também poderá afetar a granulação e altura das praias do TE. Vazões mais uniformes ao longo do tempo produziriam praias com granulação mais homogênea e topografia mais uniforme.

A deposição de sedimentos finos no TE pode ser intensificada também por influência do reservatório de Belo Monte, o qual será alimentado por águas desviadas da calha principal do rio Xingu na região da Volta Grande. Este reservatório poderá se tornar fonte adicional de sedimentos finos para o TE (Figura 24). Processos de eutrofização e decomposição de solo na área inundada podem aumentar a concentração de matéria orgânica particulada em suspensão. Dessa forma, os processos de fixação de barras pela vegetação poderão ocorrer de maneira mais veloz no TE. O aumento do aporte de sedimentos finos provocaria assoreamento mais veloz dos lagos e canais menores, provocando aumento do grau de amalgamento das barras. 
Além dos efeitos diretos das barragens, poderão haver efeitos indiretos, tal como a provável intensificação da erosão das margens das ilhas do TE e das margens da ria, causadas por ondulações devido ao aumento do fluxo de embarcações de grande porte no local decorrente dos processos de urbanização da região. A erosão de barras estabilizadas pode liberar areia para a construção de novas barras a jusante. Porém, poderá acelerar processos de assoreamento dos canais e restringir o transporte da carga de sedimentos de fundo para zonas a jusante do TE.

As mudanças no TE induzidas pelo Empreendimento Hidrelétrico de Belo Monte podem gerar impactos sobre as populações de quelônios. Os resultados granulométricos obtidos para as fácies de topo de barra do TE indicam ampla variabilidade granulométrica. Isto assegura que variações da temperatura do sedimento garantam a variação de temperatura necessária para indução do nascimento de quelônios de ambos os sexos. A retenção do aporte de sedimentos arenosos pelas barragens dificultará a formação de novas praias no TE, o que poderá reduzir o número de locais apropriados para nidificação, especialmente para o caso da Tartaruga-da-Amazônia cuja desova gregária requer praias relativamente amplas, com altura específica. Medidas de mitigação adotadas para a preservação dos locais de nidificação dos quelônios do TE já foram adotadas em períodos anteriores ao início das obras das barragens de Belo Monte. Isto incluiu o alteamento artificial de praias por meio da dragagem de sedimentos do canal do rio Xingu. Contudo, a adição de sedimentos arenosos mais grossos pode ter alterado as condições naturais de nidificação. Dessa forma, as praias tendem a reter menos água nos poros da zona insaturada, que causa aumento da temperatura do sedimento e induz o nascimento de fêmeas. Esta pode ser uma pressão ecológica significativa para a redução da população de quelônios. Assim, medidas mitigadoras devem considerar a variabilidade natural da granulação da areia. Praias artificiais construídas pela dragagem de areia mais grossas dos canais serão inadequadas para reconstruir praias formadas naturalmente durante a alternância entre cheias e secas do rio Xingu. 
A variabilidade natural da granulação e morfologia das praias depende do hidrodinâmica sedimentar do TE, que proporciona a formação de praias em locais diferentes ao longo do tempo (pelo menos nos últimos 1100 anos, considerando as idades OSL). As praias se formam em diversos pontos diferentes do TE ao longo do tempo, de forma que não haverá espaço para acomodar as populações de quelônios apenas nas praias protegidas pelo RANIBAMA. 


\section{Cenário Atual:}

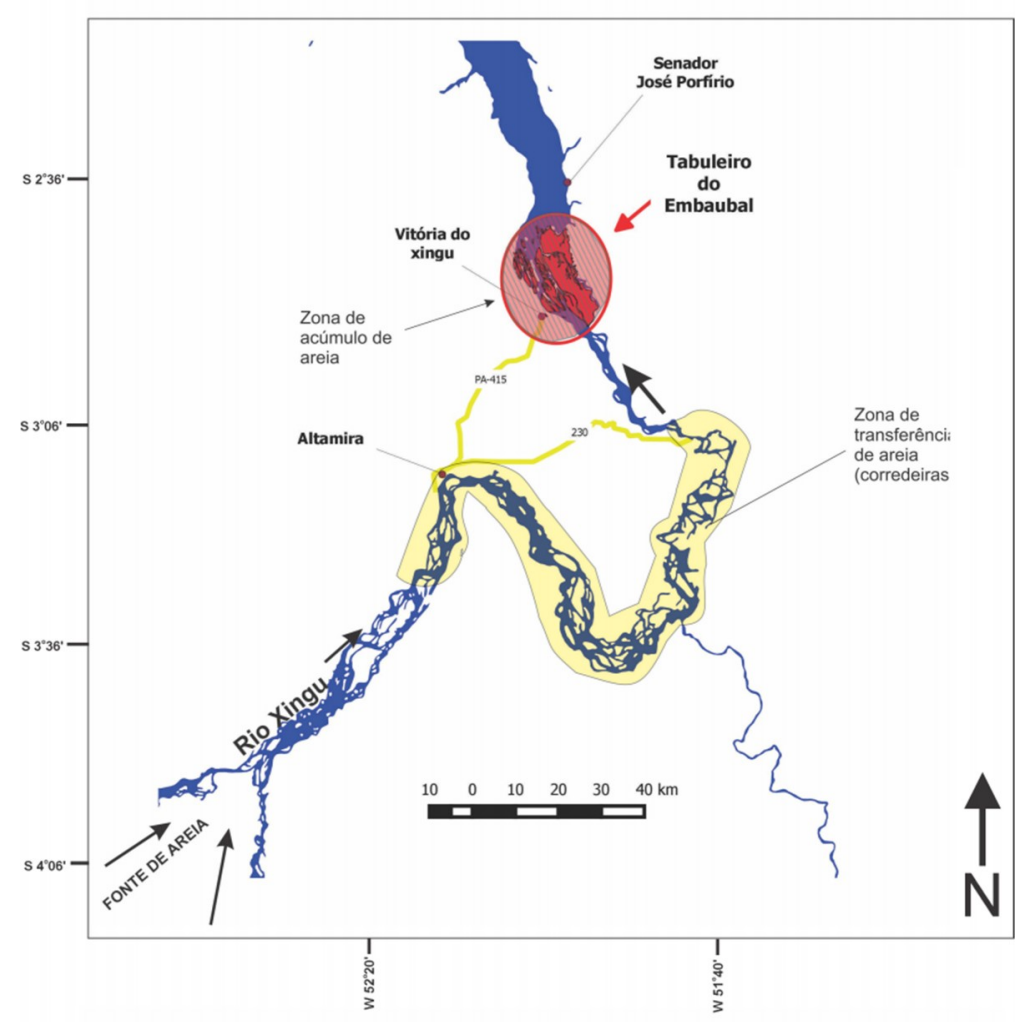

\section{Cenário Futuro:}

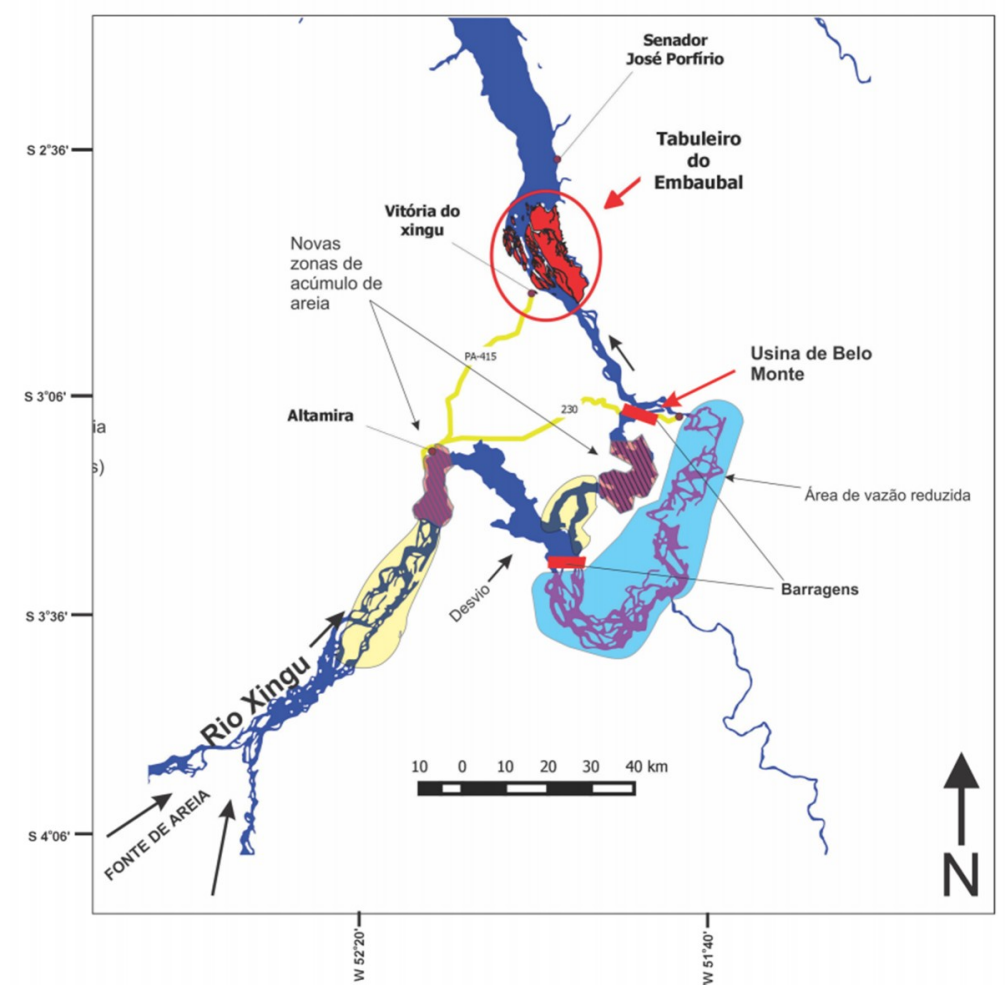

Figura 24 -Cenário futuro do TE. A carga arenosa deve ser retida a montante, formando complexos de ilhas nas cabeceiras dos reservatórios de Belo Monte. A redução do aporte sedimentar arenoso na região do TE intensificaria processos de formação de praias. 


\section{Conclusões}

$O$ arquipélago do TE possui morfologia de delta, em uma área de redução da velocidade do fluxo d'água do rio Xingu (cabeceira da ria). As ilhas do TE são grandes planícies de inundação formadas por barras fixadas pela vegetação, que por sua vez é adaptada às variações sazonais de nível d'água do rio Xingu. As ilhas emergem durante o período de seca e formam escarpas verticais ou praias em suas margens respectivamente erosivas ou deposicionais.

O substrato das ilhas é composto por fácies sedimentares dispostas em estratigrafia regular, representada principalmente por areia na base (areia fina a média silto-argilosa, A2, ou areia muito fina a fina siltosa, A1) e silte grosso arenoso no topo (S2). Ocasionalmente, fácies de silte médio argiloso orgânico (S1) ocorre entre as fácies S1 e A1/A2. Foram observados três tipos de vegetação sobre esse substrato. No interior das ilhas, ocorre vegetação arbórea formada por Florestas de Ombrófilas Densas Aluviais (mata de igapó), enquanto que nas margens ocorre vegetação arbustiva ou rasteira, formada por aningais ou por capim canarana, respectivamente.

A vegetação possui importante papel na fixação do substrato das ilhas do TE. O processo de rafting de capim canarana pode fixar barra emersa de forma rápida, promovendo a deposição de lama sobre o topo da barra e a ocupação dessa barra por mata de igapó em poucas centenas de anos. Estes processos provocam o crescimento de barras amalgamadas. As fácies A1/A2 estão associadas aos depósitos de barras ativas. A fácies S2 indica depósitos de planícies de inundação fixados pela vegetação, enquanto que a fácies S1 está associada aos lagos temporários formados no interior das ilhas que se formam nas depressões entre barras amalgamadas.

As idades OSL e ${ }^{14} \mathrm{C}$ indicaram que a maior parte das barras do Tabuleiro do Embaubal depositaram-se e foram fixadas a partir dos últimos 1100 anos. A correlação entre as idades obtidas e variações da precipitação durante 0 Holoceno na região das cabeceiras da bacia do rio Xingu sugere que os 
eventos de deposição das barras do TE se iniciou juntamente com a ativação do SAMS e foram ainda mais frequentes durante a LIA. Os processos de deposição de areias e formação de praias no TE ainda estão ativos, porém em menor intensidade em relação a LIA.

A construção da barragem de Belo Monte modificará a dinâmica sedimentar do TE. Os reservatórios das barragens passarão a ser locais de retenção das areias do Xingu, de modo que o aporte de areia para a região do TE será provavelmente reduzido. Eventos seculares a milenares de formação de praias no TE serão potencialmente interrompidos. Além disso, a granulação e altura das praias do TE poderão ser mais uniformes e o aporte de sedimentos finos e orgânicos pode ser intensificado devido à redução da variabilidade natural da vazão e nível do rio Xingu. Este cenário futuro pode gerar impactos à população dos quelônios que nidificam nas praias do TE. A interrupção ou redução da formação de praias afetaria a manutenção de praias que se formaram naturalmente nos últimos 1000 anos para acomodação das tartarugas durante o período de desova. As praias formadas neste novo cenário podem apresentar areia de granulação mais fina, menor variabilidade granulométrica e com altura mais regular. Isto pode induzir o nascimento preferencial de machos e prejudicar o sucesso reprodutivo, gerando uma nova pressão ecológica para as tartarugas. 


\section{Referências}

ALHO, C. J. R.; REIS, R. E.; AQUINO, P. P. U. 2015. Amazonian freshwater habitats experiencing environmental and socioeconomic threats affecting subsistence fisheries. Ambio.14p.

ALVES, N. DE S. 2013. Mapeamento Hidromorfodinâmico do Complexo Fluvial de Anavilhanas. Contribuição aos estudos de Geomorfologia Fluvial de rios Amazônicos. Tese de Doutorado, Universidade de São Paulo, São Paulo - SP. 232p.

AMARANTE, O. A. C. DO; ZACK, M. B. E. J.; SÁ, A. L. DE. 2001. Atlas do potencial eólico brasileiro. 44p.

ANDREAE, M. O.; ROSENFELD, D.; ARTAXO, P.; et al. 2004. Smoking rain clouds over the Amazon. Science. v. 303, n. 5662, p. 1337-1342.

ANA: Hidroweb, sistema de informações hidrológicas. Disponível em: $<$ http://hidroweb.ana.gov.br/>. Acesso em: 18, jun. 2015.

ARCHER, A. W. 2005. Review of Amazonian depositional systems. Fluvial Sedimentology VII, p. 17-39.

BAHIA, R. B. C.; FARACO, M. T. L.; MONTEIRO, M. A. S.; CAMOZZATO, E.; OLIVEIRA, M. A. O. 2004.Carta Geológica do Brasil ao Milionésimo, Sistema de Informações Geográficas. Programa Geologia do Brasil. Folha SA. 22-Belém. CPRM, Brasília.

BASTVIKEN, D.; TRANVIK, L.; DOWNING, J.; et al. 2011. the Continental Carbon Sink. Science, v. 331, n. Table 1. 50 p.

BERTANI, T. C.; ROSSETTI, D. F.; HAYAKAWA, E. H.; COHEN, M. C. L. 2015. Understanding Amazonian fluvial rias based on a Late PleistoceneHolocene analog. Earth Surface Processes and Landforms, v. 40, n. 3, p. 285-292.

VAN BREUKELEN, M. R.; VONHOF, H. B.; HELLSTROM, J. C.; WESTER, W. C. G.; KROON, D. 2008. Fossil dripwater in stalagmites reveals Holocene temperature and rainfall variation in Amazonia. Earth and Planetary Science Letters, v. 275, n. 1-2, p. 54-60.

CAMARÃO, A. P.; FILHO, A. P. DA S. S.; MARQUES, J. R. F. 2006. Gramíneas Forrageiras Nativas e Introduzidas de Terras Inundáveis da Amazônia. 75p. 
CAMARGO ET AL. 2004. Review of the Geographic Distribution of Fish Fauna of the Xingu River Basin , Brazil. Ecotropica: Society for Tropical Ecology, v. 10, p. 123-147.

CANTARELLI, V. H.; VERDADE, L. M. 2006. Alometria reprodutiva da tartaruga-da Amazônia (Podocnemis expansa): bases biológicas para 0 manejo, Tese de doutorado, Escola superior de agricultura "Luiz de Queiroz", Universidade de São Paulo, Piracicaba - SP.118 p.

CARNEIRO, C. C. 2012. Influência do ambiente de nidificação sobre a taxa de eclosão, a duração da incubação e a determinação sexual em podocnemis (reptilia, podocnemididae) no Tabuleiro do Embaubal rio xingu, Pará, Universidade Federal do Pará, Belém - PA. 54p.

CHENG, H.; SINHA, A.; CRUZ, F. W.; et al. 2013. Climate change patterns in Amazonia and biodiversity. Nature communications, v. 4, p. 1411.

COLE, J. J.; PRAIRIE, Y. T.; CARACO, N. F.; et al. 2007. Plumbing the global carbon cycle: Integrating inland waters into the terrestrial carbon budget. Ecosystems, v. 10, n. 1, p. 171-184.

CRUZ, F. W.; WANG, X.; AULER, A.; et al. 2009. Orbital and MillennialScale Precipitation Changes in Brazil from Speleothem Records. In: M. Vimeux, Francoise, Sylvestre, Florence, Khodri (Org.). Past Climate Variability in South America and Surrounding Regions. v. 14, p.29-60.

ELETROBRÁS. 2009. Aproveitamento hidrelétrico de Belo Monte Relatório de Impacto Ambiental - RIMA. 100p.

FADINI, L. S.; SILVA, A. G.; FERREIRA-JÚNIOR, P. D. 2011. Sedimentary characteristics and their effects on hatching success and incubation duration of Caretta caretta (Testudines: Cheloniidae) in Espirito Santo, Brazil. Zoologia, v. 28, n. 3, p. 312-320.

FEARNSIDE, P. M. 2001. Environmental Impacts of Brazil's Tucurui' Dam:Unlearned Lessons for Hydroelectric Development in Amazonia. Environmental Management, v. 27, n. 3, p. 377-396.

FEARNSIDE, P. M. 2006. Dams in the Amazon: Belo Monte and Brazil's hydroelectric development of the Xingu River Basin. Environmental Management, v. 38, n. 1, p. 16-27.

FERREIRA, D. B. DA S.; SOUZA, E. B. DE; MORAES, B. C. DE; MEIRA FILHO, L. G. M. 2015. Spatial and Temporal Variability of Rainfall in 
Eastern Amazon during the Rainy Season. The Scientific World Journal, v. 2015, Article ID 209783, 9p.

FERREIRA JÚNIOR, P. D.; CASTRO, A. Z.; CASTRO, P. T. A. 2007. The Importance of Nidification Environment in the Podocnemis Expansa and Podocnemis Unifilis Phenotypes (Testudines: Podocnemididae). South American Journal of Herpetology, v. 2, n. 1, p. 39-46.

FERREIRA, L. V.; CUNHA, D. A.; CHAVES, P. P.; MATOS, D. C. L.; PAROLIN, P. 2013. Impacts of hydroelectric dams on alluvial riparian plant communities in eastern Brazilian Amazonian. Anais da Academia Brasileira de Ciencias, v. 85, n. 3, p. 1013-1023.

FERREIRA, M. P. 2013. Geocronologia e proveniência dos sedimentos holocênicos da confluência dos rios Negro e Solimões, AM Geocronologia e proveniência dos sedimentos holocênicos da confluência dos rios Negro e Solimões , AM. Instituto de Geociências da Uiversidade de São Paulo.São Paulo -SP. 95p.

FUENTES, I. M. M. P. B.; MAYNARD, J. A.; GUINEA, M. 2009. Proxy indicators of sand temperature help project impacts of global warming on sea turtles in northern Australia. Endangered Species Research. p 33 40.

HAYS, G. C.; BRODERICK, A. C.; GLEN, F.; GODLEY, B. J. 2003. Climate change and sea turtles: a 150-year reconstruction of incubation temperatures at a major marine turtle rookery. Global Change Biology, v. 9 , n. 4, p. 642-646.

HUGHES, M. K.; DIAZ, H. F. 1994. Was there a "medieval warm period", and if so, where and when? Climatic Change, v. 26, n. 2-3, p. 109-142.

IBGE. 2012. Manual Técnico da Vegetação Brasileira. Manuais técnicos em geociências n.1, 271p.

INMET. 1992. Normais Climatológicas do Brasil:1961-1990. Disponível em: <http://www.inmet.gov.br/portal/index.php?r=clima/normaisclimatologicas>. Acesso em: 18, jun. 2015.

LATRUBESSE, E. M.; STEVAUX, J. C.; SINHA, R. 2005. Tropical rivers. Geomorphology, v. 70, n. 3-4, p. 187-206.

MARENGO, J. A.; HASTENRATH, S. 1993. Case studies of extreme climatic events in the Amazon Basin. Journal of Climate, v. 5, n. 4, p 617627. 
MATSUZAWA, Y.; SATO, K.; SAKAMOTO, W.; BJORNDAL, K. A. 2002. Seasonal fluctuations in sand temperature: Effects on the incubation period and mortality of loggerhead sea turtle (Caretta caretta) preemergent hatchlings in Minabe, Japan. Marine Biology, v. 140, n. 3, p. 639-646.

MATTHEWS, J. A.; BRIFFA, K. R. 2005. The "Little Ice Age": Reevaluation of an evolving concept. Geografiska Annaler, Series A: Physical Geography, v. 87, n. 1, p. 17-36.

MINELI, R. C. 2013. Proveniência e retrabalhamento sedimentar das areias da Volta Grande do rio Xingu , PA. Dissertação de Mestrado. Tese de mestrado. Universidade de São Paulo, São Paulo - SP. 63p.

NILSSON, C.; BERGGREN, K. 2000. Alterations of Riparian Ecosystems Caused by River Regulation. BioScience, v. 50, n. 9, p. 783.

NORTE ENERGIA. 2011. Usina hidrelétrica de Belo Monte: Projeto Básico Ambiental. Volume VII, Tomo 3: Estudo hidrossedimentológico à jusante da casa de força. 260p.

PEARSE, D. E.; ARNDT, A. D.; VALENZUELA, N.; et al. 2006. Estimating population structure under nonequilibrium conditions in a conservation context: continent-wide population genetics of the giant Amazon river turtle, Podocnemis expansa (Chelonia; Podocnemididae). Molecular ecology, v. 15, n. 4, p. 985-1006.

PEEL, M. C.; FINLAYSON, B. L.; MCMAHON, T. A. 2007. Updated world map of the $\mathrm{K}$ oppen-Geiger climate classification. Hydrologycal Earth Systems Science Discussion, v. 4, p. 439-473.

PRESCOTT, J. R.; STEPHAN, L. G. 1982. The contribution of cosmic radiation to the environmental dose for thermoluminescence dating. Latitude, altitude and depth dependences. 1982. v. 6, p.17-25.

RIBAS, C. C.; ALEIXO, A.; NOGUEIRA, A. C. R.; MIYAKI, C. Y.; CRACRAFT, J. 2012. A palaeobiogeographic model for biotic diversification within Amazonia over the past three million years. Proceedings of the Royal Society B: Biological Sciences, v. 279, n. 1729, p. 681-689.

ROSENBERG, D. M.; BERKES, F.; BODALY, R. A.; et al. 1997. Largescale impacts of hydroelectric development. Environmental Reviews, v. 5, n. 1 , p. $27-54$. 
SAWAKUCHI, H. O.; BASTVIKEN, D.; SAWAKUCHI, A. O.; et al. 2014. Methane emissions from Amazonian Rivers and their contribution to the global methane budget. Global Change Biology, v. 20, n. 9, p. 28292840.

SILVA, J. M. C.; RYLANDS, A. B.; DA FONSECA, G. A B. 2005. The fate of Amazonian of endemism. Conservation Biology, v. 19, n. 3, p. 689694.

SIOLI, H. 1984. The Amazon and its main affluents: Hydrography, morphology of the river courses, and river types. In: H. Sioli (Org.); The Amazon SE - 5, Monographiae Biologicae. Editado por Springer Netherlands v. 56, p.127-165.

SOARES, E. A. A.; TATUMI, S. H.; RICCOMINI, C. 2010. OSL age determinations of Pleistocene fluvial deposits in Central Amazonia. Anais da Academia Brasileira de Ciências, v. 82, n. 3, p. 691-699.

SPEAKMAN, J. R.; HAYS, G. C.; LINDBLAD, E. 1998. Thermal conductivity of sand and its effect on the temperature of loggerhead sea turtle (Caretta caretta) nests. Journal of the Marine Biological Association of the United Kingdom, v. 78, n. 4, p. 1337-1352.

STICKLER, C. M.; COE, M. T.; COSTA, M. H.; et al. 2011. Dependence of hydropower energy generation on forests in the Amazon Basin at local and regional scales. Proceedings of the National Academy of Sciences of the United States of America, v. 110, n. 23, p. 9601-6.

STUIVER, M.; REIMER, P. J. 1993. Extended 14C data base and revised CALIB 3.0 14C age calibration program. Radiocarbon, v. 35, n. 1, p. 215230.

SYVITSKI, J. P. M.; COHEN, S.; KETTNER, A. J.; BRAKENRIDGE, G. R. 2014. How important and different are tropical rivers? - An overview.

Geomorphology. Disponível em:

<http://dx.doi.org/10.1016/j.geomorph.2014.02.029> acesso em 18, jun, 2015.

VUILLE, M.; BURNS, S. J.; TAYLOR, B. L.; et al. 2012. A review of the South American monsoon history as recorded in stable isotopic proxies over the past two millennia. Climate of the Past, v. 8, n. 4, p. 1309-1321.

YANG, Z.; WANG, H.; SAITO, Y.; et al. 2006. Dam impacts on the Changjiang (Yangtze) River sediment discharge to the sea: The past 55 years and after the Three Gorges Dam. Water Resources Research, v. 42, n. 4. 